\title{
The Community Oncology and Academic Medical Center Alliance in the Age of Precision Medicine: Cancer Genetics and Genomics Considerations
}

\author{
Marilena Melas ${ }^{1} @$, Shanmuga Subbiah ${ }^{2}$, Siamak Saadat ${ }^{3}$, Swapnil Rajurkar ${ }^{4}$ and \\ Kevin J. McDonnell 5,6,* \\ 1 The Steve and Cindy Rasmussen Institute for Genomic Medicine, Nationwide Children's Hospital, \\ Columbus, OH 43205, USA; Marilena.Melas@nationwidechildrens.org \\ 2 Department of Medical Oncology and Therapeutics Research, City of Hope Comprehensive Cancer Center, \\ Glendora, CA 91741, USA; ssubbiah@coh.org \\ 3 Department of Medical Oncology and Therapeutics Research, City of Hope Comprehensive Cancer Center, \\ Colton, CA 92324, USA; ssaadat@coh.org \\ 4 Department of Medical Oncology and Therapeutics Research, City of Hope Comprehensive Cancer Center, \\ Upland, CA 91786, USA; srajurkar@coh.org \\ 5 Department of Medical Oncology and Therapeutics Research, City of Hope Comprehensive Cancer Center \\ and Beckman Research Institute, Duarte, CA 91010, USA \\ 6 Center for Precision Medicine, City of Hope Comprehensive Cancer Center, Duarte, CA 91010, USA \\ * Correspondence: kemcdonnell@coh.org
}

Received: 13 June 2020; Accepted: 2 July 2020; Published: 6 July 2020

\begin{abstract}
Recent public policy, governmental regulatory and economic trends have motivated the establishment and deepening of community health and academic medical center alliances. Accordingly, community oncology practices now deliver a significant portion of their oncology care in association with academic cancer centers. In the age of precision medicine, this alliance has acquired critical importance; novel advances in nucleic acid sequencing, the generation and analysis of immense data sets, the changing clinical landscape of hereditary cancer predisposition and ongoing discovery of novel, targeted therapies challenge community-based oncologists to deliver molecularly-informed health care. The active engagement of community oncology practices with academic partners helps with meeting these challenges; community/academic alliances result in improved cancer patient care and provider efficacy. Here, we review the community oncology and academic medical center alliance. We examine how practitioners may leverage academic center precision medicine-based cancer genetics and genomics programs to advance their patients' needs. We highlight a number of project initiatives at the City of Hope Comprehensive Cancer Center that seek to optimize community oncology and academic cancer center precision medicine interactions.
\end{abstract}

Keywords: community oncology; academic cancer center; precision medicine; cancer genetics; cancer genomics

\section{Introduction}

Historically, the practice and delivery of healthcare in the community contrasted significantly with medical care provided at the academic medical center [1,2]. These differences manifested across specialty practices, including oncology [3,4]. Rapid advances in molecular diagnostics, the advent of targeted therapies and the introduction of precision medicine amplified differences between community and academic oncology practices [5,6]. Reversing this historical divide, however, new financial realities, public policy initiatives and legislative mandateshave forced community oncologists and academic 
cancer centers to more closely align their healthcare efforts [7]. This forced alliance has lessened the separation between community and academic oncology practices and permitted broader access and utilization of precision medicine-based cancer genetics services and tumor genomic analyses. The alliance between community and academic oncology expands the capabilities and effectiveness of the community practitioner, reinforces the mission of the academic cancer center and, ultimately, secures better oncologic care for the cancer patient.

\section{The Emergence and Evolution of the Community Health Care and Academic Medical Center Alliance}

A number of key distinctions differentiate the medical care provided at community health centers (CHCs) versus academic health centers (AHCs); these differences result in complementary advantages. The overwhelming majority of patients receive their healthcare through $\mathrm{CHCs}$; the $\mathrm{CHC}$ patient population typically exhibits great diversity across economic, racial, ethnic and social spectra [8]. CHCs offer their patients increased accessibility and enhanced client engagement [9]. In contrast, AHCs, characteristically, have focused on specialty medical care, biomedical research, the education and training of health care professionals and the stopgap provision of health care to uninsured and destitute populations [10]. These activities underlie the strengths of AHCs. These strengths include the presence of medical expertise, scientific innovation and clinical trial availability; additionally, AHCs possess unique physical resources such as libraries, computerized database management and informatics infrastructure, research laboratories and emergency room facilities [11,12]. Leveraging these strengths, AHCs have established their reputations and acquired leadership roles in shaping medical care and policy [10].

Until two decades ago, CHCs and AHCs functioned largely in parallel, without administrative or operational intersection. A variety of recent economic, social and regulatory circumstances, however, diminished the independence of AHCs. With the rise of community-based health care markets, particularly managed care plans, many of the operations traditionally carried out at AHCs shifted to CHCs; this shift often undercut the previously reliable revenue streams of AHCs. This situation forced reconsideration of the AHC financial model and provided impetus for the implementation of more efficient, cost-effective health care delivery strategies [13-18]. At the same time, governmental funding agencies, to ensure faithful representation of population diseases, placed a premium on the inclusion of community patients into research protocols. These agencies also issued directives to AHCs to provide comprehensive population care and mandated the formal reporting of AHC involvement with community patient populations [19-25]. Overall, these influences forced AHCs to redefine their core mission with a new emphasis on the integration of the $\mathrm{CHC}$ and their patient populations [26-28]. Given their previous work in shaping medical policy, their stewardship of medical education, and their diverse and extensive resources, AHCs readily assumed a leadership role in the restructuring of the CHC/AHC relationship and the creation of integrated partnerships [2,29-35].

The alliance between CHCs and AHCs provides advantages to both partners. CHCs and AHCs enjoy better positioning within the healthcare marketplace. The improved marketplace positioning results primarily from economy of scale pricing that accompanies the integration and expansion of patient services, procedures and therapeutics; the alliance secures for both partners more stable financial footings [36]. The alliance makes possible specific benefits for the $\mathrm{CHC}$. This alliance permits the $\mathrm{CHC}$ more direct access to AHC-generated experimental therapeutics, clinical trials, translational research, medical devices and protocols [37]. Further, evidence suggests that affiliation with an AHC often enhances the prestige and attractiveness of the $\mathrm{CHC}$, increases patient and clinical staff retention, fosters more opportunity for continuing professional development, frequently results in greater professional satisfaction and has the potential to enhance the quality and efficacy of the CHC [38-40]. For the AHC, partnerships with a $\mathrm{CHC}$ allow for enhanced opportunities to interact more tangibly with the community patient population and expand and diversify patient pools for translational research and clinical trial enrollment; partnerships also increase the ability of AHCs to mitigate outcomes and 
patient access disparities [41]. Multiple examples of successful CHC/AHC partnerships exist; they serve as models for the feasibility and potential future CHC/AHC partnerships [42-44].

\section{Community Oncology and Academic Cancer Center Alliance}

The integration of CHCs with AHCs most tangibly manifests as practice changes within specific departments, including, prominently, medical oncology [45-51]. During recent years cancer care has transitioned from primarily private, CHC-based oncology practices to AHC-affiliated and -integrated network cancer centers [51-55]. This transition has advantaged the community cancer patient as the services associated with the academic cancer center provide added value.

At the City of Hope Comprehensive Cancer Center (COHCCC), patients identify a number of key value elements associated with the academic cancer center including access to cancer disease specialists, the availability of clinical, translational and basic science researchers, potential for clinical trial participation and enhanced comprehensive care coordinated through multidisciplinary clinical teams [56].

Across a broad range of cancers, patients experience improved survival when receiving treatment at an academic cancer center or at a community hospital associated with an AHC [57-64]. Academic cancer centers provide additional value to community practices through the discovery and provision of novel drugs, experimental medical devices, treatment protocols and technological advancements [65-71]. Reciprocally, academic cancer centers benefit from their alliance with community oncology practices by expanding clinical trial portfolios [72-74], increasing patient diversity in cancer translational and basic research initiatives [75-79], enhancing cancer center core mission accomplishment through community cancer patient engagement [80] and reducing cancer care costs resulting from increased patient volumes [81].

The introduction of new technologies and scientific techniques underscores the importance and potential of the alliance between community oncology practices and academic cancer centers. Specifically, recent advances in genetics and tumor genomics have provided a foundation for the emergence of precision oncology; the community/academic oncology alliance promises to accelerate significantly the clinical utility of precision oncology for the cancer care of community patients [82-85].

\section{The Age of Precision Oncology}

Cancers exhibit highly complex genomic and epigenomic alterations; these alterations dictate their overall phenotypic behavior that includes growth characteristics, metastatic potential, interplay between cells and microenvironmental interactions and responses. Over the past several decades, scientific strategies to prevent, diagnose and treat cancer have radically shifted from histology-based to genomically- and immunologically-informed approaches [86].

Since completion of the Human Genome Project in 2003 [87], a series of convergent technological advances resulted from academic-based initiatives. These advances include the introduction and adoption of next generation nucleic acid sequencing (NGS), exponential improvements in computer hardware capabilities, optimization of data processing approaches, evolution of increasingly sophisticated computational biological methods and the discovery and utilization of targeted cancer therapies. Together these advances made possible precision medicine and, more exactly, precision oncology [82,88-90].

NGS arose from innovative DNA sequencing methodologies, most notably massively parallel signature sequencing [91,92]. NGS permits tractable high throughput sequencing of immensely large and complex DNA samples such as whole human exomes and genomes [93,94]. Geneticists first employed NGS to sequence accurately and rapidly the human germline genome [95], allowing insights into the cause of inherited disease [96,97]; investigators then extended the technology to sequence somatic cancer genomes [98]. Scientists further refined the applications of NGS technology. New applications permitted assessment of not only single nucleotide variation and nucleotide insertions and deletions, but also the transcriptome to assess gene expression [99-101], copy number variation [102], 
complex genomic structural variation [103], protein-DNA interactions [104], targetable epigenetic alterations [105] and epigenetic mechanisms regulating 3D genome structure [106].

In addition to examining tumor genomics, there arose an interest in understanding the immune profiles of the tumor and its microenvironment using NGS; in part, this interest developed from the recognition that tumor genomic changes frequently result in the production of unique, highly immunogenic neoantigens that render the tumor vulnerable to immune surveillance and destruction $[107,108]$. With the appreciation that the immune system plays an important role in cancer initiation and progression, there has also occurred new interest in targeted therapies aimed at activation of the immune axis $[109,110]$.

NGS generates enormous caches of data; use of these immense data sets for precision oncology requires ever increasing levels of computer hardware performance. Employment of Dennard scaling [111] and multicore architectures [112] have sustained exponential increases in computer chip performance [113-115]. Data processing innovations have included parallel algorithm implementation [116] and parallel data computing [117]; such innovations have force multiplied the efficiency and speed of computation. These approaches allow data analysts to keep pace with the ever increasing information workloads of precision oncology [118].

The realization of precision oncology required adoption of computational biological approaches. The creation of computational biology as an independent academic discipline resulted from the complexity and size of biological data sets. In the case of NGS, the sheer number of nucleotides reads, the task of aligning these reads to reference sequences, predicting functional consequences of genomic variation and the translation of these findings into clinically actionable information necessitated computational biological expertise [119-122]. Computational biological analysis now constitutes an integral element of the data workflow in precision oncology [123-126]; effective clinical translation depends inextricably upon the availability of these computational resources [127-130].

In the early 1970's, Drs. Janet Rowley, Peter Nowell and Alfred Knudson, studying leukemia cell chromosomes under the microscope, suggested that a specific chromosomal translocation that resulted in the formation of the BCR-ABL fusion oncogene caused chronic myelogenous leukemia (CML); this observation established a foundation for clinical cancer genomics [131]. Oncogenic proteins consequently became a focus of therapeutic drug design; targeted therapies aimed to suppress the aberrant functions of these proteins in order to inhibit tumor progression [132,133].

The successful harnessing of precision therapeutics in oncology ultimately relies upon the availability and efficacy of targeted agents. The discovery that imatinib effectively treats CML harboring the BCR-ABL fusion protein [134] led to the drug's FDA approval in 2001 [135], demonstrated the utility of targeted cancer therapy [136,137], kindled enthusiasm for the identification of other genetically vulnerable cancers and their treatments $[90,138]$ and underscored the clinical value and potential of precision oncology $[98,139,140]$. Since the success of imatinib, the FDA has approved a multitude of additional therapies to target molecularly-altered cancers [141,142].

The clinical provision of precision oncology requires multidisciplinary support [143]; the complexity of this support will become more intense as precision oncology continues to undergo accelerating change [144-146]. AHCs possess the resources and organization to create this support structure; their alliance with $\mathrm{CHC}$ oncology practitioners will make precision oncology available to the larger $\mathrm{CHC}$ cancer population.

\section{The Community Oncology/Academic Cancer Center Alliance in Germline Cancer Genetics}

NGS and precision oncology have had a profound effect upon the practice of cancer genetics, including the evaluation and care of community patients with hereditary predisposition to cancer [147-151]. Until recently, genetic testing involved clinical assessment followed by sequential, single gene Sanger sequencing of suspect genes [152-156]. The advent of NGS brought high throughput germline multigene panel [157-161], whole exome [162-167] and whole genome assessment [168-172] to clinical cancer genetics. These platforms provide tremendous benefit to cancer genetics patients both 
in community oncology practices and at academic cancer centers; these advantages include increased diagnostic yield, increased speed of testing, optimized testing workflows, decreased expense and the discovery of new cancer-causing genes [173-177]. However, together with advantages, challenges and limitations arise; AHCs have the specialized resources to address these issues.

In accordance with the American College of Medical Genetics and the Association for Molecular Pathology guidelines, variants from clinical genetic testing fall along a spectrum ranging from pathogenic/likely pathogenic to benign/likely benign [178]; variants of uncertain significance (VUS) occur when there exists insufficient information for variant assignment to either the pathogenic or benign categories $[179,180]$. For pathogenic/likely pathogenic and benign/likely benign variants, genetic providers typically have the ability to communicate clear interpretation of results and to provide consensus health recommendations. As their pathogenicity remains uncertain, VUS challenge health care specialists to formulate and relay unambiguous health care instructions [181-185]; furthermore, VUS frequently cause confusion and anxiety for the patient [186-190]. VUS impose a significant clinical burden. More than one third of NGS-based cancer gene panel tests result in identification of a VUS [191]; whole exome and genome testing generate even greater numbers of VUS [192-195]. Moreover, if a patient belongs to a minority group, for whom genome annotations remain less well confirmed, VUS additionally increase [196].

Geneticists classify genes according to their penetrance, that is, how likely will a pathogenic variant of a gene cause disease [197]. For pathogenic variants of high penetrance genes, clinicians more often have firmly established guidelines that inform recommendations for patient screening and surveillance. However, for pathological variants of low penetrance genes, less definitive clinical guidelines exist. NGS-based testing results in increasing detection of pathogenic variants of low penetrance genes; this increased detection adds complexity and uncertainty to patient management $[198,199]$.

Clinicians face another challenge when selecting NGS gene panels for genetic evaluation: they must select the composition of the gene panel that they will employ. This selection requires specialized education and training [200,201]. The cancer genetics expertise required to address this challenge remains scarce [202-205]; the wider use of NGS platforms in clinical oncology and continued technological advances has made this expertise even more scarce [206-208].

AHCs possess the clinical expertise, facilities, support personnel, and administrative structures to meet the burgeoning demands of cancer genetics and to overcome the obstacles associated with the use of NGS in the clinic. Allied community oncology practices and their patients have access to these resources and services through their partnerships with AHCs. Four access models enable community oncology patient engagement with the AHC: (1) patient consultation visits to the academic cancer center, (2) cancer genetics specialist visits to community oncology sites, (3) telemedicine- and web-based remote visits and (4) AHC-sponsored genetic education initiatives that train community oncology practitioners to assess and manage cancer genetic risk and disease (Figure 1).

Conventionally, community oncology patients have received their cancer genetics care by consulting, in person, with a specialist at an AHC [155,209-211]. This model disadvantages community patients who live substantial distances from an AHC as it involves significant travel time and cost commitments $[210,212,213]$. Alternative cancer genetics delivery models have the potential to mitigate these problems.

In the community satellite clinic model, AHC cancer genetic specialists travel to the $\mathrm{CHC}$ clinic on an interval basis to meet the cancer genetic needs of community patients. This approach has proven successful in a variety of circumstances where logistical or economic challenges create barriers to effective cancer genetics care [214-217]. 


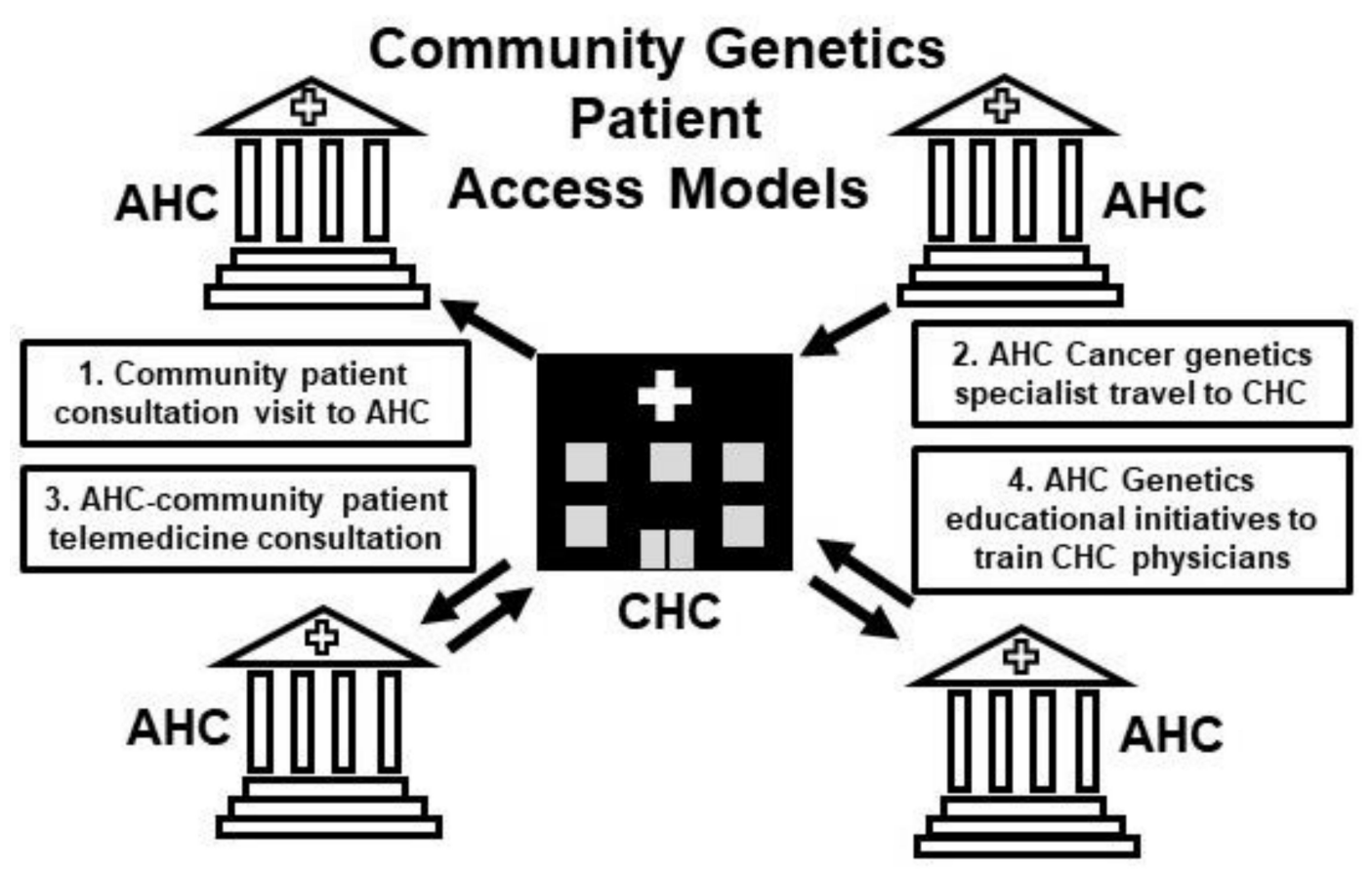

Figure 1. Community health center $(\mathrm{CHC})$ patients requiring genetics care interface with specialists at academic health centers (AHC) through four modes of interaction. (1) The CHC patient may travel to the AHC for assessment. (2) The AHC genetics specialist may travel to a satellite $\mathrm{CHC}$ genetics clinic to evaluate the $\mathrm{CHC}$ patient. (3) $\mathrm{CHC}$ patients and AHC genetic specialists may interact via telemedicine consultation. (4) In order to provide genetics care to their patients, $\mathrm{CHC}$ physicians may undergo genetics specialty training sponsored by AHCs.

In our digital era, innovative cancer genetics delivery models have emerged; telemedicine platforms that involve both telephony and video communication platforms represent one such model [218-222]. The Division of Clinical Cancer Genetics (CCG) at COHCCC has assumed a national leadership position in the adoption of digital age technologies to provide academic center cancer genetic services to community oncology practices and their patients.

The CCG formed the Cancer Screening and Program Network (CSPPN), building a bridge to community oncology practices; the CSPPN utilizes innovative videoconferencing, telemedicine and wed-based applications to provide cancer genetics services [223]. Innovation continues at the CCG with the ongoing construction of new software and web-based platforms to permit effective communication between academic cancer genetics providers and community-based patients and practitioners [224].Alongside the use of these digital platforms, the CCG has administered a landmark educational program to provide community oncology healthcare providers with the necessary training that allows them to function as competent cancer risk assessment specialists in their own communities [225]. This program, funded by the National Cancer Institute, has expanded the workforce of qualified germline genetics providers and has helped to alleviate the shortage of cancer genetics expertise in CHC practices.

Educational programs, such as that sponsored by the CCG, have acquired additional practical importance as many healthcare systems now require, prior to genetic testing, assessment by a healthcare provider trained in genetics. These requirements may hinder effective cancer genetics care, particularly in underserved communities [226]; the availability of training will help eliminate this hindrance.

\section{The Community Oncology/Academic Cancer Center Alliance in Somatic Tumor Genomics}

The use of clinical NGS in oncology has risen exponentially [227]. Hundreds of commercial and academic laboratories now offer NGS-based clinical sequencing of cancer specimens $[119,228]$. The NGS sequencing formats for somatic tumor sequencing include, among others, whole exome, 
whole genome, targeted panel, transcriptome and liquid biopsy assessments [229-235]. Various factors have driven the increased clinical application of NGS for somatic tumor assessment. The number of targetable genomic alterations increases substantially each year. Currently, there exist well over one hundred FDA-approved targeted therapies available for the treatment of both solid and hematological cancers [98]; over the past year alone, the FDA granted approval to nearly 20 new drugs or new indications for previously approved drugs [96]. With inclusion of therapy based upon molecular pathway considerations or off-label usage based on tissue-agnostic variant matching, the set of molecular targets and usage indications expands geometrically [236-244]. Purposing NGS-based somatic testing to determine clinical trial eligibility further increases the utility of NGS [245-248]; moreover, the demonstrated efficacy of testing to achieve improved outcomes has also motivated demand [248-252]. The decision by the Centers for Medicare and Medicaid Services to provide insurance coverage for NGS-based sequencing tests removed a financial barrier against the use of NGS, and contributed to the expanded use of this technology [253-255]. All told, currently over three quarters of oncologists use now NGS-base clinical testing to guide treatment decisions [256].

Significant challenges, however, temper enthusiasm for the clinical institution of somatic tumor NGS. A majority of oncologists report difficulty interpreting NGS somatic tumor testing, lack understanding of the clinical indications for testing and have inadequate opportunities to acquire the necessary training to properly use testing. One quarter of oncologists refer patients to other specialists to assist with NGS testing, and approximately 1 in 5 oncologists did not feel they had the proper knowledge to use properly NGS testing [256-258]. Additionally, oncologists report challenges with managing the large data volumes generated from NGS somatic testing. Oncologists also feel that they do not have the ability to distill from these reports actionable information; further, they lack the skill to manage germline variants detected as incidental findings in somatic NGS tumor testing [259-262]. These obstacles may be amplified for the CHC-based oncologist who lacks access to the necessary computational resources, logistical support and expertise in targeted therapeutics [263-266].

The CHC/AHC alliance provides solutions to alleviate these obstacles. Innovative AHC-based web applications make available to community oncologists an analytic framework and the computational tools to aid in the interpretation and clinical implementation of NGS sequencing results (Table 1). $\mathrm{CIViC}$, an open access web resource, serves as a public central repository of NGS data "supporting clinical interpretations related to cancer" [267]. OncoKB, a precision oncology database, aids therapeutic decision-making based upon cancer gene variant status [268]; similarly, the web applications Personalized Cancer Therapy and My Cancer Genome assist both community and academic oncologists in selecting therapeutic options resulting from the somatic NGS of tumor specimens $[269,270]$. The SMART Cancer Navigator aggregates variant and clinical data from multiple data bases to assist community-based oncologists with the processing of NGS reports and the identification of effective targeted therapies [271]. At the COHCCC, investigators have configured an interactive web interface, HOPE-Genomics, that community patients and oncologists may use to better understand genomic sequencing results and treatment recommendations [224]. The COHCCC also provides to its community practice partners in-house NGS panel testing as part of its HOPESEQ molecular testing panel [272]; HOPESEQ includes genomic test reports designed to assist clinicians with interpreting the genetic testing results and clinical decision making. Furthermore, COHCCC physicians and community partners have access to Via Oncology; this tool provides a web-based clinical pathway system to help match patients with clinical trials and insurance reimbursement for NGS driven treatments [273].

Precision oncology tumor boards (POTBs) represent another solution to the problem of implementing NGS data in the CHC oncology clinic. POTBs arose from the need to assess, process and generate clinical treatment plans from the highly dense and complex data sets that arise from somatic NGS of tumor specimens [274]. POTBs serve two primary functions: targeted therapy drug matching and molecularly-informed clinical trial enrollment [275-280] (Figure 2). 
Table 1. Web-based genomics resources available to community oncologists.

\begin{tabular}{ll}
\hline WEB-BASED RESOURCE & URL \\
\hline CIViC & civicdb.org \\
\hline OncoKB & oncokb.org \\
\hline Personalized Cancer Therapy & pct.mdanderson.org \\
\hline My Cancer Genome & mycancergenome.org \\
\hline SMART Cancer Navigator & smart-cancer-navigator.github.io/home \\
\hline ASCO Multidisciplinary Molecular Tumor Boards & $\begin{array}{l}\text { elearning.asco.org/product-details/ } \\
\text { multidisciplinary-molecular-tumor/boards-mmtbs }\end{array}$ \\
\hline Helio Learn Genomics & healio.com \\
\hline Know Your Tumor & pancan.org \\
\hline
\end{tabular}

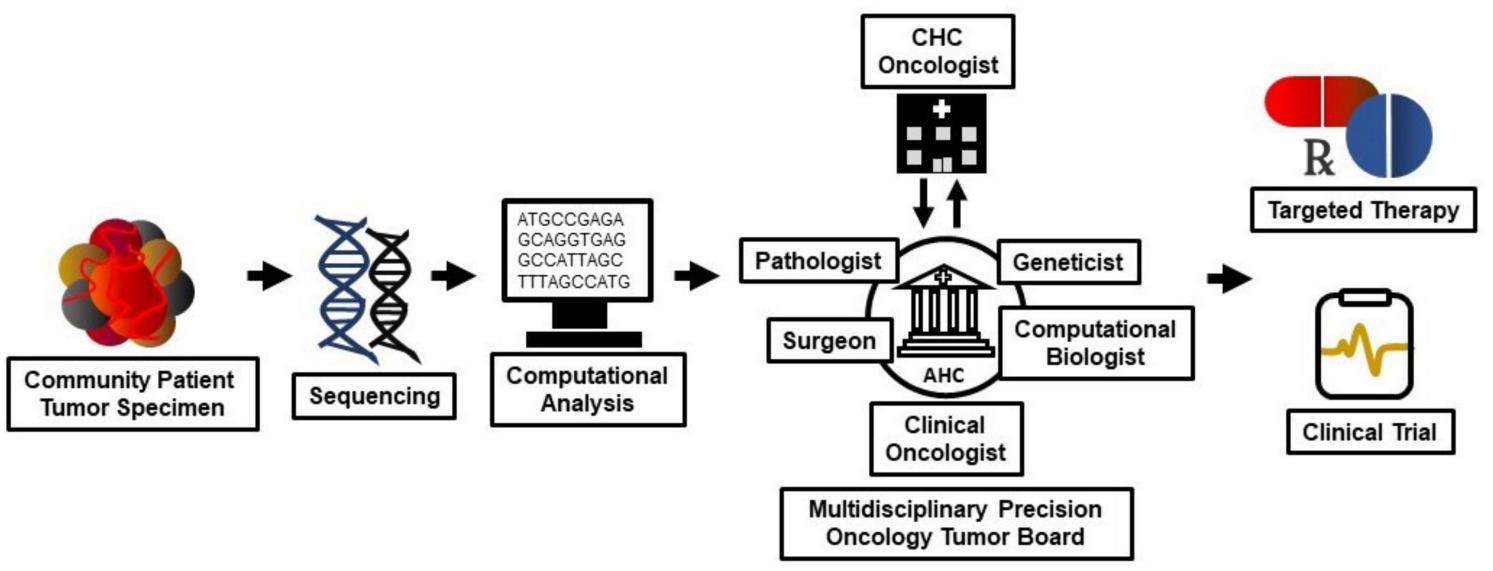

Figure 2. Multidisciplinary precision oncology tumor boards (POTBs) provide expert targeted drug matching and molecularly informed clinical trial enrollment for community oncology patients. Tumor specimens from community patients undergo nucleic acid sequencing with computational analysis to identify molecular alterations; this information provides a basis to discover candidate targeted therapies and determine clinical trial eligibility. An academic health center (AHC) POTB comprising, among others, clinical oncologists, pathologists, surgeons, geneticists and computational biologists, in consultation with community health center $(\mathrm{CHC})$ oncologists, reviews patients' clinical cases and their sequencing results to select appropriate targeted therapies and clinical trials.

POTBs originated within AHCs as these centers possess the multidisciplinary expertise including, among others, clinical oncologists, pathologists, genomics specialists, computational biologists, pharmacologists and clinical geneticists to efficiently identify targeted therapies and clinical trials [281-290]. Targeted therapy drug matching requires comprehensive molecular mutational profiling and downstream pathway analyses of the tumor, combined with the identification of safe and effective therapeutic agents that redress these molecular alterations [291-293]; CHCs typically do not possess the analytic or pharmacologic capabilities to adequately perform these activities. Most clinical trials fail [294-296]; these failures result from a number of factors including deficient clinical trial design, poor proof of concept planning and insufficient administrative support and compliance [297-300]. Such failures have adverse consequences for both the clinical trial sponsors as well as the patients; failure has significant economic cost and results in lost therapeutic opportunity, in addition to potentially exposing the patient to harm from the investigational protocol and drugs [301-303]. These clinical trial-related matters may be more acute at $\mathrm{CHCs}$ given their more limited resources and the absence of experienced clinical trialists [304-307]. The POTB provides appropriate, molecularly-informed clinical trial assignment for patients, maximizing both the utility of clinical trial participation and potential patient benefit [308-320]. 
Given the resource limitations of the $\mathrm{CHC}$ oncology clinic, community POTB operation requires innovation and dedicated planning [83,321,322]. One innovation available to community oncologists, the web-based ASCO Multidisciplinary Molecular Tumor Boards, assists oncologists with understanding precision medicine-based tumor testing and the therapy recommendations resulting from these tests [323] (Table 1). Helio Learn Genomics, another web platform, offers a number of educational modules, including РОТВ cases, to help providers understand the molecular bases of carcinogenesis and precision therapeutics [324]. The Pancreatic Cancer Action Network administers a Know Your Tumor program, a turn-key precision medicine initiative, that allows community oncology practitioners to submit their patients' pancreatic cancer specimens for NGS molecular testing and to receive back a precision medicine-based treatment plan [325].

Another version of the POTB, the virtual POTB, permits the distance participation of community oncologists in an academic POTB. In this model an AHC hosts the POTB and reviews the clinical history and precision oncology testing results of the community oncology patient; subsequently, the POTB discusses with the community oncologist, using a live interactive video teleconferencing link, targeted treatment and clinical trial recommendations [263,311,326-330]. The Translational Genomics Research Institute (TGEN), an academic affiliate of the COHCCC, has successfully built a comprehensive, integrated, high-throughput sequencing and reporting framework that, when combined with remote teleconferencing, has proven tremendously successful in establishing efficient collaborative POTBs [331-335]. Together, these various models of providing clinical somatic NGS demonstrate the feasibility of leveraging precision oncology for the community-based cancer oncologist and their patients.

\section{Conclusions}

We have entered the age of precision oncology. Precision oncology offers the potential of molecularly informed medicine for the assessment of inherited cancer predisposition, as well as for the diagnosis and treatment of cancers. Realization of this potential depends upon access to specialized expertise and significant analytic and technological resources. While frequently available at AHCs, these resources have previously been limited for $\mathrm{CHC}$ oncology practices and their patients. In this paper, we have examined the $\mathrm{CHC} / \mathrm{AHC}$ alliance and discussed examples illustrating how this alliance provides a structure that allows community cancer patients to benefit from germline and somatic precision oncology advances. Looking forward, multidisciplinary efforts, improved technology and continuing innovation promise to strengthen and facilitate the CHC/AHC alliance in oncology; this alliance offers community oncologists and their patients the prospect of unambiguous interpretation of genetic and genomic test results and optimized precision oncology care.

Author Contributions: Writing-Original Draft Preparation, M.M., S.S. (Shanmuga Subbiah), K.J.M.; Writing-Review and Editing, S.S. (Swapnil Rajurkar). All authors have read and agreed to the published version of the manuscript.

Funding: This research received no external funding.

Conflicts of Interest: The authors declare no conflict of interest.

\section{References}

1. Wartman, S.A. The Transformation of Academic Health Centers: Meeting The Challenges Of Healthcare's Changing Landscape; Academic Press: Fribourg, Switzerland, 2015.

2. Dzau, V.J.; Ackerly, D.C.; Sutton-Wallace, P.; Merson, M.H.; Williams, R.S.; Krishnan, K.R.; Taber, R.C.; Califf, R.M. The role of academic health science systems in the transformation of medicine. Lancet 2010, 375, 949-953. [CrossRef]

3. Desch, C.E.; Blayney, D.W. Making the choice between academic oncology and community practice: the big picture and details about each career. J. Oncol. Pract. 2006, 2, 132-136. [CrossRef]

4. Todd, R.F., III. A guide to planning careers in hematology and oncology. Hematol. Am. Soc. Hemat. 2001, 2001, 499-506. [CrossRef] [PubMed] 
5. Levit, L.A.; Kim, E.S.; McAneny, B.L.; Nadauld, L.D.; Levit, K.; Schenkel, C.; Schilsky, R.L. Implementing precision medicine in community-based oncology programs: Three models. J. Oncol. Pract. 2019, 15, 325-329. [CrossRef] [PubMed]

6. Thompson, M.A.; Godden, J.J.; Weissman, S.M.; Wham, D.; Wilson, A.; Ruggeri, A.; Mullane, M.P.; Weese, J.L. Implementing an oncology precision medicine clinic in a large community health system. Am. J. Manag. Care 2017, 23, SP425-SP427.

7. Levine, D.M.; Becker, D.M.; Bone, L.R.; Hill, M.N.; Tuggle, M.B., II; Zeger, S.L. Community-academic health center partnerships for underserved minority populations. One solution to a national crisis. J. Am. Med. Assoc. 1994, 272, 309-311. [CrossRef]

8. Shin, P.; Sharac, J.; Rosenbaum, S. Community health centers and medicaid at 50: An. Enduring relationship essential for health system transformation. Health Aff. (Millwood) 2015, 34, 1096-1104. [CrossRef]

9. Sharma, A.E.; Huang, B.; Knox, M.; Willard-Grace, R.; Potter, M.B. Patient engagement in community health center leadership: How does it happen? J. Community Health 2018, 43, 1069-1074. [CrossRef] [PubMed]

10. Blumenthal, D.; Meyer, G.S. Academic health centers in a changing environment. Health Aff. (Millwood) 1996, 15, 200-215. [CrossRef]

11. Nash, D.B.; Veloski, J.J. Emerging opportunities for educational partnerships between managed care organizations and academic health centers. West. J. Med. 1998, 168, 319-327. [PubMed]

12. Roper, W.L.; Newton, W.P. The role of academic health centers in improving health. Ann. Fam. Med. 2006, 4 , S55-S57. [CrossRef] [PubMed]

13. Blumenthal, D.; Meyer, G.S. The future of the academic medical center under health care reform. N. Engl. J. Med. 1993, 329, 1812-1814. [CrossRef]

14. Fox, P.D.; Wasserman, J. Academic medical centers and managed care: Uneasy partners. Health Aff. (Millwood) 1993, 12, 85-93. [CrossRef]

15. Epstein, A.M. US teaching hospitals in the evolving health care system. J. Am. Med. Assoc. 1995, 273, 1203-1207. [CrossRef]

16. Iglehart, J.K. Academic medical centers enter the market: The case of Philadelphia. N. Engl. J. Med. 1995, 333, 1019-1023. [CrossRef] [PubMed]

17. Lofgren, R.; Karpf, M.; Perman, J.; Higdon, C.M. The U.S. health care system is in crisis: Implications for academic medical centers and their missions. Acad. Med. 2006, 81, 713-720. [CrossRef]

18. Park, B.; Frank, B.; Likumahuwa-Ackman, S.; Brodt, E.; Gibbs, B.K.; Hofkamp, H.; DeVoe, J. Health equity and the tripartite mission: Moving from academic health centers to academic-community health systems. Acad. Med. 2019, 94, 1276-1282. [CrossRef]

19. Bartlett, S.J.; Barnes, T.; McIvor, R.A. Integrating patients into meaningful real-world research. Ann. Am. Thorac. Soc. 2014, 11, S112-S117. [CrossRef]

20. Gourevitch, M.N. Population health and the academic medical center: The time is right. Acad. Med. 2014, 89, 544-549. [CrossRef] [PubMed]

21. Vitale, K.; Newton, G.L.; Abraido-Lanza, A.F.; Aguirre, A.N.; Ahmed, S.; Esmond, S.L.; Evans, J.; Gelmon, S.B.; Hart, C.; Hendricks, D.; et al. Community engagement in academic health centers: A model for capturing and advancing our successes. J. Commun. Engagem. Scholarsh. 2018, 10, 81-90.

22. Zerhouni, E. Medicine: The NIH roadmap. Science 2003, 302, 63-72. [CrossRef] [PubMed]

23. Schwenk, T.L.; Green, L.A. The Michigan Clinical Research Collaboratory: Following the NIH Roadmap to the community. Ann. Fam. Med. 2006, 4, S49-S54. [CrossRef] [PubMed]

24. Zerhouni, E.A. Translational and clinical science-Time for a new vision. N. Engl. J. Med. 2005, 353, 1621-1623. [CrossRef] [PubMed]

25. Zerhouni, E.A. US biomedical research: Basic, translational, and clinical sciences. J. Am. Med. Assoc. 2005, 294, 1352-1358. [CrossRef]

26. Kassirer, J.P. Academic medical centers under siege. N. Engl. J. Med. 1994, 331, 1370-1371. [CrossRef]

27. Iglehart, J.K. Rapid changes for academic medical centers. 2. N. Engl. J. Med. 1995, 332, 407-411. [CrossRef]

28. Iglehart, J.K. Rapid changes for academic medical centers. 1. N. Engl. J. Med. 1994, 331, 1391-1395. [CrossRef]

29. Moses, H., III; Matheson, D.H.M.; Poste, G. Serving individuals and populations within integrated health systems: A bridge too far? J. Am. Med. Assoc. 2019, 321, 1975-1976. [CrossRef]

30. Cutler, D.M.; Morton, F.S. Hospitals, market share, and consolidation. J. Am. Med. Assoc. 2013, 310, 1964-1970. [CrossRef] 
31. Moses, H., III; Matheson, D.H.; Dorsey, E.R.; George, B.P.; Sadoff, D.; Yoshimura, S. The anatomy of health care in the United States. J. Am. Med. Assoc. 2013, 310, 1947-1963. [CrossRef]

32. Cohen, M.D.; Jennings, G. Mergers involving academic medical institutions: Impact on academic radiology departments. J. Am. Coll. Radiol. 2005, 2, 174-182. [CrossRef] [PubMed]

33. Denham, A.C.; Hay, S.S.; Steiner, B.D.; Newton, W.P. Academic health centers and community health centers partnering to build a system of care for vulnerable patients: Lessons from Carolina Health Net. Acad. Med. 2013, 88, 638-643. [CrossRef] [PubMed]

34. Rieselbach, R.E.; Rieselbach, R.E.; Epperly, T.; Friedman, A.; Keahey, D.; McConnell, E.; Nichols, K.; Nycz, G.; Roberts, J.; Schmader, K.; et al. A new community health center/academic medicine partnership for medicaid cost control, powered by the Mega Teaching Health Center. Acad. Med. 2018, 93, 406-413. [CrossRef]

35. Blumenthal, D.; Campbell, E.G.; Weissman, J.S. The social missions of academic health centers. N. Engl. J. Med. 1997, 337, 1550-1553. [CrossRef]

36. Fleishon, H.B.; Itri, J.N.; Boland, G.W.; Duszak, R., Jr. Academic medical centers and community hospitals integration: Trends and strategies. J. Am. Coll. Radiol. 2017, 14, 45-51. [CrossRef]

37. Ellner, A.L.; Stout, S.; Sullivan, E.E.; Griffiths, E.P.; Mountjoy, A.; Phillips, R.S. Health systems innovation at academic health centers: Leading in a new era of health care delivery. Acad. Med. 2015, 90, 872-880. [CrossRef] [PubMed]

38. Moore, G.T.; Inui, T.S.; Ludden, J.M.; Schoenbaum, S.C. The "teaching HMO": A new academic partner. Acad. Med. 1994, 69, 595-600. [CrossRef] [PubMed]

39. Poncelet, A.N.; Mazotti, L.A.; Blumberg, B.; Wamsley, M.A.; Grennan, T.; Shore, W.B. Creating a longitudinal integrated clerkship with mutual benefits for an academic medical center and a community health system. Perm. J. 2014, 18, 50-56. [CrossRef]

40. Berkowitz, S.A.; Brown, P.; Brotman, D.J.; Deutschendorf, A.; Dunbar, L.; Everett, A.; Hickman, D.; Howell, E.; Purnell, L.; Sylvester, C.; et al. Case Study: Johns Hopkins Community Health Partnership: A model for transformation. Healthc (Amst.) 2016, 4, 264-270. [CrossRef]

41. Institute of Medicine (US) Committee on Understanding and Eliminating Racial and Ethnic Disparities in Health Care. Unequal Treatment: Confronting Racial and Ethnic Disparities in Health Care; Smedley, B.D., Stith, A.Y., Nelson, A.R., Eds.; National Academies Press: Washington, DC, USA, 2003.

42. Ahmed, S.M.; Maurana, C.; Nelson, D.; Meister, T.; Young, S.N.; Lucey, P. Opening the black box: Conceptualizing community engagement from 109 community-academic partnership programs. Prog. Community Health Partnersh. 2016, 10, 51-61. [CrossRef]

43. Croft, C.R.; Dial, R.; Doyle, G.; Schaadt, J.; Merchant, L. Integrating a community hospital-based radiology department with an academic medical center. J. Am. Coll. Radiol. 2016, 13, 300-302. [CrossRef]

44. Sussman, A.J.; Otten, J.R.; Goldszer, R.C.; Hanson, M.; Trull, D.J.; Paulus, K.; Brown, M.; Dzau, V.; Brennan, T.A. Integration of an academic medical center and a community hospital: The Brigham and Women's/Faulkner hospital experience. Acad. Med. 2005, 80, 253-260. [CrossRef] [PubMed]

45. Spalluto, L.B.; Thomas, D.; Beard, K.R.; Campbell, T.; Audet, C.M.; McBride Murry, V.; Shrubsole, M.J.; Barajas, C.P.; Joosten, Y.A.; Dittus, R.S.; et al. A community-academic partnership to reduce health care disparities in diagnostic imaging. J. Am. Coll. Radiol. 2019, 16, 649-656. [CrossRef] [PubMed]

46. Kelley-Quon, L.I.; Thomas, D.; Beard, K.R.; Campbell, T.; Audet, C.M.; McBride Murry, V.; Shrubsole, M.J.; Barajas, C.P.; Joosten, Y.A.; Dittus, R.S.; et al. Academic-community partnerships improve outcomes in pediatric trauma care. J. Pediatr. Surg. 2015, 50, 1032-1036. [CrossRef] [PubMed]

47. Phillip, C.R.; Mancera-Cuevas, K.; Leatherwood, C.; Chmiel, J.S.; Erickson, D.L.; Freeman, E.; Granville, G.; Dollear, M.; Walker, K.; McNeil, R.; et al. Implementation and dissemination of an African American popular opinion model to improve lupus awareness: An academic-community partnership. Lupus 2019, 28, 1441-1451. [CrossRef] [PubMed]

48. Rees, T. Academic medical center, community hospital partner to market center of excellence. Profiles Healthc. Mark. 1999, 15, 40-43.

49. Yaggy, S.D.; Michener, J.L.; Yaggy, D.; Champagne, M.T.; Silberberg, M.; Lyn, M.; Johnson, F.; Yarnall, K.S. Just for Us: An academic medical center-community partnership to maintain the health of a frail low-income senior population. Gerontologist 2006, 46, 271-276. [CrossRef]

50. Natesan, R.; Yang, W.T.; Tannir, H.; Parikh, J. Strategic expansion models in academic radiology. J. Am. Coll. Radiol. 2016, 13, 329-334. [CrossRef] 
51. Kirkwood, M.K.; Hanley, A.; Bruinooge, S.S.; Garrett-Mayer, E.; Levit, L.A.; Schenkel, C.; Seid, J.E.; Polite, B.N.; Schilsky, R.L. The State of oncology practice in America, 2018: results of the ASCO practice census survey. J. Oncol. Pract. 2018, 14, e412-e420. [CrossRef]

52. OBR New Perspective Catalyst. Most Cancer Patients Will Be Treated in Integrated Delivery Networks (IDN) and Cancer Institutions by 2016, Predicts New Report; OBR New Perspective Catalyst: Sausalito, CA, USA, 2012; Volume 11.

53. Genetech. The 2018 Genentech Oncology Trend Report; Genetech: San Francisco, CA, USA, 2018.

54. Genetech. The 2019 Genentech Oncology Trend Report; Genetech: San Francisco, CA, USA, 2019.

55. Academic Cancer Centers (NCCC). Trends Impacting Key Account. Management; Academic Cancer Centers: Pipersville, PA, USA, 2016.

56. Nardi, E.A.; Wolfson, J.A.; Rosen, S.T.; Diasio, R.B.; Gerson, S.L.; Parker, B.A.; Alvarnas, J.C.; Levine, H.A.; Fong, Y.; Weisenburger, D.D.; et al. Value, access, and cost of cancer care delivery at academic cancer centers. J. Natl. Compr. Cancer Netw. 2016, 14, 837-847. [CrossRef]

57. Speicher, P.J.; Englum, B.R.; Ganapathi, A.M.; Wang, X.; Hartwig, M.G.; D'Amico, T.A.; Berry, M.F. Traveling to a high-volume center is associated with improved survival for patients with esophageal cancer. Ann. Surg. 2017, 265, 743-749. [CrossRef] [PubMed]

58. Lidsky, M.E.; Sun, Z.; Nussbaum, D.P.; Adam, M.A.; Speicher, P.J.; Blazer, D.G., III. Going the extra mile: Improved survival for pancreatic cancer patients traveling to high-volume centers. Ann. Surg. 2017, 266, 333-338. [CrossRef] [PubMed]

59. David, J.M.; Ho, A.S.; Luu, M.; Yoshida, E.J.; Kim, S.; Mita, A.C.; Scher, K.S.; Shiao, S.L.; Tighiouart, M.; Zumsteg, Z.S. Treatment at high-volume facilities and academic centers is independently associated with improved survival in patients with locally advanced head and neck cancer. Cancer 2017, 123, 3933-3942. [CrossRef]

60. Chen, A.Y.; Fedewa, S.; Pavluck, A.; Ward, E.M. Improved survival is associated with treatment at high-volume teaching facilities for patients with advanced stage laryngeal cancer. Cancer 2010, 116, 4744-4752. [CrossRef] [PubMed]

61. Pfister, D.G.; Rubin, D.M.; Elkin, E.B.; Neill, U.S.; Duck, E.; Radzyner, M.; Bach, P.B. Risk adjusting survival outcomes in hospitals that treat patients with cancer without information on cancer stage. JAMA Oncol. 2015, 1, 1303-1310. [CrossRef] [PubMed]

62. Schmitz, R.; Adam, M.A.; Blazer, D.G., III. Overcoming a travel burden to high-volume centers for treatment of retroperitoneal sarcomas is associated with improved survival. World J. Surg. Oncol. 2019, 17, 180. [CrossRef] [PubMed]

63. Dillman, R.O.; Chico, S.D. Cancer patient survival improvement is correlated with the opening of a community cancer center: Comparisons with intramural and extramural benchmarks. J. Oncol. Pract. 2005, 1, 84-92. [CrossRef] [PubMed]

64. Ramalingam, S.; Dinan, M.A.; Crawford, J. Survival comparison in patients with stage iv lung cancer in academic versus community centers in the United States. J. Thorac. Oncol. 2018, 13, 1842-1850. [CrossRef] [PubMed]

65. Carugo, A.; Draetta, G.F. Academic discovery of anticancer drugs: Historic and future perspectives. Ann. Rev. Cancer Biol. 2019, 3, 385-408. [CrossRef]

66. Everett, J.R. Academic drug discovery: Current status and prospects. Expert Opin. Drug Discov. 2015, 10, 937-944. [CrossRef] [PubMed]

67. Matter, A. Bridging academic science and clinical research in the search for novel targeted anti-cancer agents. Cancer Biol. Med. 2015, 12, 316-327. [PubMed]

68. Dorfman, G.S.; Lawrence, T.S.; Matrisian, L.M.; Translational Research Working Group. The Translational Research Working Group developmental pathway for interventive devices. Clin. Cancer Res. 2008, 14, 5700-5706. [CrossRef] [PubMed]

69. Barrios, C.H.; Reinert, T.; Werutsky, G. Global breast cancer research: Moving forward. Am. Soc. Clin. Oncol. Educ. Book. 2018, 38, 441-450. [CrossRef] [PubMed]

70. Huber, M.A.; Kraut, N. Key drivers of biomedical innovation in cancer drug discovery. EMBO Mol. Med. 2015, 7, 12-16. [CrossRef] [PubMed] 
71. Grodzinski, P.; Liu, C.H.; Hartshorn, C.M.; Morris, S.A.; Russell, L.M. NCI Alliance for Nanotechnology in Cancer-From academic research to clinical interventions. Biomed. Microdev. 2019, 21, 32. [CrossRef] [PubMed]

72. Clauser, S.B.; Johnson, M.R.; O’Brien, D.M.; Beveridge, J.M.; Fennell, M.L.; Kaluzny, A.D. Improving clinical research and cancer care delivery in community settings: Evaluating the NCI community cancer centers program. Implement. Sci. 2009, 4, 63. [CrossRef]

73. Hirsch, B.R.; Locke, S.C.; Abernethy, A.P. Experience of the national cancer institute community cancer centers program on community-based cancer clinical trials activity. J. Oncol. Pract. 2016, 12, e350-8. [CrossRef]

74. Copur, M.S.; Ramaekers, R.; Gonen, M.; Gulzow, M.; Hadenfeldt, R.; Fuller, C.; Scott, J.; Einspahr, S.; Benzel, H.; Mickey, M.; et al. Impact of the national cancer institute community cancer centers program on clinical trial and related activities at a community cancer center in rural Nebraska. J. Oncol. Pract. 2016, 12, 67-68. [CrossRef]

75. DH, F. Clinical trials have the best medicine but do not enroll the patients who need it. Sci. Am. 2019, 320, 61-65.

76. Copur, M.S. Inadequate awareness of and participation in cancer clinical trials in the community oncology setting. Oncology 2019, 33, 54-57.

77. Green, M.A.; Michaels, M.; Blakeney, N.; Odulana, A.A.; Isler, M.R.; Richmond, A.; Long, D.G.; Robinson, W.S.; Taylor, Y.J.; Corbie-Smith, G. Evaluating a community-partnered cancer clinical trials pilot intervention with African American communities. J. Cancer Educ. 2015, 30, 158-166. [CrossRef] [PubMed]

78. Best, A.; Hiatt, R.A.; Cameron, R.; Rimer, B.K.; Abrams, D.B. The evolution of cancer control research: An international perspective from Canada and the United States. Cancer Epidemiol Biomarkers Prev. 2003, 12, 705-712. [PubMed]

79. Greenwald, P.; Cullen, J.W. The new emphasis in cancer control. J. Natl. Cancer. Inst. 1985, 74, 543-551. [CrossRef]

80. Noel, L.; Phillips, F.; Tossas-Milligan, K.; Spear, K.; Vanderford, N.L.; Winn, R.A.; Vanderpool, R.C.; Eckhardt, S.G. Community-academic partnerships: Approaches to engagement. Am. Soc. Clin. Oncol. Educ. Book. 2019, 39, 88-95. [CrossRef]

81. Harris, A.; Kumar, P.; Sutaria, S. Unlocking the Potential of Acdemic and Community Health System Partnerships; McKinsey and Company: New York, NY, USA, 2015.

82. Johnson, T.M. Perspective on precision medicine in oncology. Pharmacotherapy 2017, 37, 988-989. [CrossRef] [PubMed]

83. Ersek, J.L.; Black, L.J.; Thompson, M.A.; Kim, E.S. Implementing precision medicine programs and clinical trials in the community-based oncology practice: Barriers and best practices. Am. Soc. Clin. Oncol. Educ. Book. 2018, 38, 188-196. [CrossRef]

84. Nadauld, L.D.; Ford, J.M.; Pritchard, D.; Brown, T. Strategies for clinical implementation: Precision oncology at three distinct institutions. Health Aff. (Millwood) 2018, 37, 751-756. [CrossRef]

85. Thompson, M.A.; Godden, J.J.; Wham, D.; Ruggeri, A.; Mullane, M.P.; Wilson, A.; Virani, S.; Weissman, S.M.; Ramczyk, B.; Vanderwall, P.; et al. Coordinating an oncology precision medicine clinic within an integrated health system: lessons learned in year one. J. Patient Cent. Res. Rev. 2019, 6, 36-45. [CrossRef]

86. Carpten, J.C.; Mardis, E.R. The era of precision oncogenomics. Cold Spring Harb. Mol. Case Stud. $2018,4$. [CrossRef]

87. International Human Genome Sequencing Consortium. Finishing the euchromatic sequence of the human genome. Nature 2004, 431, 931-945. [CrossRef]

88. Ashley, E.A. Towards precision medicine. Nat. Rev. Genet. 2016, 17, 507-522. [CrossRef] [PubMed]

89. Sanchez, N.S.; Mills, G.B.; Mills Shaw, K.R. Precision oncology: Neither a silver bullet nor a dream. Pharmacogenomics 2017, 18, 1525-1539. [CrossRef] [PubMed]

90. Berger, M.F.; Mardis, E.R. The emerging clinical relevance of genomics in cancer medicine. Nat. Rev. Clin. Oncol. 2018, 15, 353-365. [CrossRef] [PubMed]

91. Mitra, R.D.; Church, G.M. In situ localized amplification and contact replication of many individual DNA molecules. Nucleic Acids Res. 1999, 27, e34. [CrossRef]

92. Brenner, S.; Johnson, M.; Bridgham, J.; Golda, G.; Lloyd, D.H.; Johnson, D.; Luo, S.; McCurdy, S.; Foy, M.; Ewan, M.; et al. Gene expression analysis by massively parallel signature sequencing (MPSS) on microbead arrays. Nat. Biotechnol. 2000, 18, 630-634. [CrossRef] 
93. Mardis, E.R. Next-generation DNA sequencing methods. Annu. Rev. Genomics Hum. Genet. 2008, 9, 387-402. [CrossRef]

94. Shendure, J.; Ji, H. Next-generation DNA sequencing. Nat. Biotechnol. 2008, 26, 1135-1145. [CrossRef] [PubMed]

95. Bentley, D.R.; Balasubramanian, S.; Swerdlow, H.P.; Smith, G.P.; Milton, J.; Brown, C.G.; Hall, K.P.; Evers, D.J.; Barnes, C.L.; Bignell, H.R.; et al. Accurate whole human genome sequencing using reversible terminator chemistry. Nature 2008, 456, 53-59. [CrossRef] [PubMed]

96. Mardis, E.R. The impact of next-generation sequencing technology on genetics. Trends Genet. 2008, 24, 133-141. [CrossRef]

97. Tucker, T.; Marra, M.; Friedman, J.M. Massively parallel sequencing: The next big thing in genetic medicine. Am. J. Hum. Genet. 2009, 85, 142-154. [CrossRef]

98. Ley, T.J.; Mardis, E.R.; Ding, L.; Fulton, B.; McLellan, M.D.; Chen, K.; Dooling, D.; Dunford-Shore, B.H.; McGrath, S.; Hickenbotham, M.; et al. DNA sequencing of a cytogenetically normal acute myeloid leukaemia genome. Nature 2008, 456, 66-72. [CrossRef] [PubMed]

99. Reinartz, J.; Bruyns, E.; Lin, J.Z.; Burcham, T.; Brenner, S.; Bowen, B.; Kramer, M.; Woychik, R. Massively parallel signature sequencing (MPSS) as a tool for in-depth quantitative gene expression profiling in all organisms. Brief. Funct. Genomic. Proteomic. 2002, 1, 95-104. [CrossRef] [PubMed]

100. Torres, T.T.; Metta, M.; Ottenwalder, B.; Schlotterer, C. Gene expression profiling by massively parallel sequencing. Genome Res. 2008, 18, 172-177. [CrossRef] [PubMed]

101. Cancer Genome Atlas Research, N.; Weinstein, J.N.; Collisson, E.A.; Mills, G.B.; Shaw, K.R.; Ozenberger, B.A.; Ellrott, K.; Shmulevich, I.; Sander, C.; Stuart, J.M. The cancer genome atlas pan-cancer analysis project. Nat. Genet. 2013, 45, 1113-1120.

102. Wang, H.; Nettleton, D.; Ying, K. Copy number variation detection using next generation sequencing read counts. BMC Bioinform. 2014, 15, 109. [CrossRef] [PubMed]

103. Medvedev, P.; Stanciu, M.; Brudno, M. Computational methods for discovering structural variation with next-generation sequencing. Nat. Methods 2009, 6, S13-S20. [CrossRef]

104. Johnson, D.S.; Mortazavi, A.; Myers, R.M.; Wold, B. Genome-wide mapping of in vivo protein-DNA interactions. Science 2007, 316, 1497-1502. [CrossRef]

105. Morel, D.; Jeffery, D.; Aspeslagh, S.; Almouzni, G.; Postel-Vinay, S. Combining epigenetic drugs with other therapies for solid tumours-Past lessons and future promise. Nat. Rev. Clin. Oncol. 2020, 17, 91-107. [CrossRef]

106. Lazaris, C.; Aifantis, I.; Tsirigos, A. On epigenetic plasticity and genome topology. Trends Cancer 2020, 6, 177-180. [CrossRef]

107. Segal, N.H.; Parsons, D.W.; Peggs, K.S.; Velculescu, V.; Kinzler, K.W.; Vogelstein, B.; Allison, J.P. Epitope landscape in breast and colorectal cancer. Cancer Res. 2008, 68, 889-892. [CrossRef]

108. Alexandrov, L.B.; Nik-Zainal, S.; Wedge, D.C.; Aparicio, S.A.; Behjati, S.; Biankin, A.V.; Bignell, G.R.; Bolli, N.; Borg, A.; Borresen-Dale, A.L.; et al. Signatures of mutational processes in human cancer. Nature 2013, 500, 415-421. [CrossRef] [PubMed]

109. Sanmamed, M.F.; LChe. A paradigm shift in cancer immunotherapy: From enhancement to normalization. Cell 2018, 175, 313-326. [CrossRef] [PubMed]

110. Zewde, M.; Kiyotani, K.; Park, J.H.; Fang, H.; Yap, K.L.; Yew, P.Y.; Alachkar, H.; Kato, T.; Mai, T.H.; Ikeda, Y.; et al. The era of immunogenomics/immunopharmacogenomics. J. Hum. Genet. 2018, 63, 865-875. [CrossRef]

111. Dennard, R.H.; Gaensslen, F.H.; Yu, H.N.; Rideout, V.L.; Bassous, E.; Leblanc, A.R. Design of ion-implanted MOSFET's with very small physical dimensions. IEEE J. Solid State Circuits 1974, 9, 256-268. [CrossRef]

112. Gorder, P.F. Multicore processors for science and engineering. Comput. Sci. Eng. 2007, 9, 3-7. [CrossRef]

113. Denning, P.J.; Lewis, T.G. Exponential laws of computing growth. Commun. Acm 2017, 60, 54-65. [CrossRef]

114. Thackray, A.; Brock, D.C. Moore's Law: The Life of Gordon Moore, Silicon Valley's Quiet Revolutionary; Basic Books: New York, NY, USA, 2015.

115. Koomey, J.G.; Berard, S.; Sanchez, M.; Wong, H. Implications of historical trends in the electrical efficiency of computing. IEEE Comput. Soc. 2011, 33, 46-54. [CrossRef]

116. Hill, M.D.; Marty, M.R. Amdahl's law in the multicore era. Computer 2008, 41, 33. [CrossRef]

117. Denning, P.J.; Tichy, W.F. Highly parallel computation. Science 1990, 250, 1217-1222. [CrossRef] 
118. Hinkson, I.V.; Davidsen, T.M.; Klemm, J.D.; Kerlavage, A.R.; Kibbe, W.A.; Chandramouliswaran, I. A comprehensive infrastructure for big data in cancer research: Accelerating cancer research and precision medicine. Front. Cell. Dev. Biol. 2017, 5, 83. [CrossRef]

119. Wing, J.M. Computational thinking. Commun. Acm 2006, 49, 33-35. [CrossRef]

120. Regev, A.; Shapiro, E. Cellular abstractions: Cells as computation. Nature 2002, 419, 343-343. [CrossRef] [PubMed]

121. Searls, D.B. The roots of bioinformatics. PLoS Comput. Biol. 2010, 6. [CrossRef]

122. Moorthie, S.; Hall, A.; Wright, C.F. Informatics and clinical genome sequencing: Opening the black box. Genet. Med. 2013, 15, 165-171. [CrossRef] [PubMed]

123. Funari, V.; Canosa, S. The importance of bioinformatics in NGS: Breaking the bottleneck in data interpretation. Science 2014, 344, 653-653. [CrossRef]

124. Oliver, G.R.; Hart, S.N.; Klee, E.W. Bioinformatics for clinical next generation sequencing. Clin. Chem. 2015, 61, 124-135. [CrossRef] [PubMed]

125. Gullapalli, R.R.; Lyons-Weiler, M.; Petrosko, P.; Dhir, R.; Becich, M.J.; LaFramboise, W.A. Clinical integration of next-generation sequencing technology. Clin. Lab. Med. 2012, 32, 585-599. [CrossRef]

126. Hundal, J.; Miller, C.A.; Griffith, M.; Griffith, O.L.; Walker, J.; Kiwala, S.; Graubert, A.; McMichael, J.; Coffman, A.; Mardis, E.R. Cancer immunogenomics: computational neoantigen identification and vaccine design. Cold Spring Harb. Symp. Quant. Biol. 2016, 81, 105-111. [CrossRef]

127. Tenenbaum, J.D. Translational bioinformatics: Past, present, and future. Genom. Proteomics Bioinform. 2016, 14, 31-41. [CrossRef]

128. Weissenbach, J. The rise of genomics. C R Biol. 2016, 339, 231-239. [CrossRef]

129. Morganti, S.; Tarantino, P.; Ferraro, E.; D’Amico, P.; Viale, G.; Trapani, D.; Duso, B.A.; Curigliano, G. Complexity of genome sequencing and reporting: Next generation sequencing (NGS) technologies and implementation of precision medicine in real life. Crit. Rev. Oncol. Hematol. 2019, 133, 171-182. [CrossRef] [PubMed]

130. Koboldt, D.C.; Steinberg, K.M.; Larson, D.E.; Wilson, R.K.; Mardis, E.R. The next-generation sequencing revolution and its impact on genomics. Cell 2013, 155, 27-38. [CrossRef] [PubMed]

131. Nowell, P.C.; Rowley, J.D.; Knudson, A.G., Jr. Cancer genetics, cytogenetics-Defining the enemy within. Nat. Med. 1998, 4, 1107-1111. [CrossRef]

132. Druker, B.J.; Lydon, N.B. Lessons learned from the development of an abl tyrosine kinase inhibitor for chronic myelogenous leukemia. J. Clin. Invest. 2000, 105, 3-7. [CrossRef] [PubMed]

133. Rossari, F.; Minutolo, F.; Orciuolo, E. Past, present, and future of Bcr-Abl inhibitors: From chemical development to clinical efficacy. J. Hematol. Oncol. 2018, 11, 84. [CrossRef]

134. Druker, B.J.; Talpaz, M.; Resta, D.J.; Peng, B.; Buchdunger, E.; Ford, J.M.; Lydon, N.B.; Kantarjian, H.; Capdeville, R.; Ohno-Jones, S.; et al. Efficacy and safety of a specific inhibitor of the BCR-ABL tyrosine kinase in chronic myeloid leukemia. N. Engl. J. Med. 2001, 344, 1031-1037. [CrossRef]

135. Savage, D.G.; Antman, K.H. Imatinib mesylate-A new oral targeted therapy. N. Engl. J. Med. 2002, 346, 683-693. [CrossRef]

136. Lee, Y.T.; Tan, Y.J.; Oon, C.E. Molecular targeted therapy: Treating cancer with specificity. Eur. J. Pharmacol. 2018, 834, 188-196. [CrossRef]

137. Scholl, C.; Frohling, S. Exploiting rare driver mutations for precision cancer medicine. Curr. Opin. Genet. Dev. 2019, 54, 1-6. [CrossRef]

138. Jackson, S.E.; Chester, J.D. Personalised cancer medicine. Int. J. Cancer 2015, 137, 262-266. [CrossRef]

139. Neal, J.W.; Sledge, G.W. Decade in review-targeted therapy: Successes, toxicities and challenges in solid tumours. Nat. Rev. Clin. Oncol. 2014, 11, 627-628. [CrossRef] [PubMed]

140. Prasad, V.; Fojo, T.; MBrad. Precision oncology: Origins, optimism, and potential. Lancet Oncol. 2016, 17, e81-e86. [CrossRef]

141. El-Deiry, W.S.; Goldberg, R.M.; Lenz, H.J.; Shields, A.F.; Gibney, G.T.; Tan, A.R.; Brown, J.; Eisenberg, B.; Heath, E.I.; Phuphanich, S.; et al. The current state of molecular testing in the treatment of patients with solid tumors, 2019. Cancer J. Clin. 2019, 69, 305-343. [CrossRef] [PubMed]

142. National Cancer Institute. Targeted Cancer Therapies. Available online: https://www.cancer.gov/aboutcancer/treatment/types/targeted-therapies/targeted-therapies-fact-sheet (accessed on 2 July 2020). 
143. Khotskaya, Y.B.; Mills, G.B.; Mills Shaw, K.R. Next-Generation Sequencing and Result Interpretation in Clinical Oncology: Challenges of Personalized Cancer Therapy. Annu. Rev. Med. 2017, 68, 113-125. [CrossRef]

144. Buchanan, M. The law of accelerating returns. Nat. Phys. 2008, 4, 507-507. [CrossRef]

145. Kurzweil, R. The Law of Accelerating Returns. 2001. Available online: https://www.kurzweilai.net/the-lawof-accelerating-returns (accessed on 12 April 2020).

146. Blazer, K.R.; Nehoray, B.; Solomon, I.; Niell-Swiller, M.; Culver, J.O.; Uman, G.C.; Weitzel, J.N. Next-generation testing for cancer risk: Perceptions, experiences, and needs among early adopters in community healthcare settings. Genet. Test. Mol. Biomarkers 2015, 19, 657-665. [CrossRef]

147. Mauer, C.B.; Pirzadeh-Miller, S.M.; Robinson, L.D.; Euhus, D.M. The integration of next-generation sequencing panels in the clinical cancer genetics practice: An. institutional experience. Genet. Med. 2014, 16, 407-412. [CrossRef]

148. Sabour, L.; Sabour, M.; Ghorbian, S. Clinical applications of next-generation sequencing in cancer diagnosis. Pathol. Oncol. Res. 2017, 23, 225-234. [CrossRef]

149. Sylvester, D.E.; Chen, Y.; Jamieson, R.V.; Dalla-Pozza, L.; Byrne, J.A. Investigation of clinically relevant germline variants detected by next-generation sequencing in patients with childhood cancer: A review of the literature. J. Med. Genet. 2018, 55, 785-793. [CrossRef]

150. Obrochta, E.; Godley, L.A. Identifying patients with genetic predisposition to acute myeloid leukemia. Best Pract. Res. Clin. Haematol. 2018, 31, 373-378. [CrossRef]

151. Gomy, I.; Mdel, P.D. Hereditary cancer risk assessment: Insights and perspectives for the next-generation sequencing era. Genet. Mol. Biol. 2016, 39, 184-188. [CrossRef] [PubMed]

152. Pensabene, M.; Spagnoletti, I.; Capuano, I.; Condello, C.; Pepe, S.; Contegiacomo, A.; Lombardi, G.; Bevilacqua, G.; Caligo, M.A. Two mutations of BRCA2 gene at exon and splicing site in a woman who underwent oncogenetic counseling. Ann. Oncol. 2009, 20, 874-878. [CrossRef] [PubMed]

153. Kamps, R.; Brandao, R.D.; Bosch, B.J.; Paulussen, A.D.; Xanthoulea, S.; Blok, M.J.; Romano, A. Next-generation sequencing in oncology: Genetic diagnosis, risk prediction and cancer classification. Int. J. Mol. Sci. 2017, 18, 308. [CrossRef] [PubMed]

154. Domchek, S.M.; Bradbury, A.; Garber, J.E.; Offit, K.; Robson, M.E. Multiplex genetic testing for cancer susceptibility: Out on the high wire without a net? J. Clin. Oncol. 2013, 31, 1267-1270. [CrossRef]

155. Weitzel, J.N.; Blazer, K.R.; MacDonald, D.J.; Culver, J.O.; Offit, K. Genetics, genomics, and cancer risk assessment: State of the Art and future directions in the era of personalized medicine. Cancer J. Clin. 2011, 61, 327-359. [CrossRef] [PubMed]

156. Lynce, F.; Isaacs, C. How far do we go with genetic evaluation. Am. Soc. Clin. Oncol. Educ. Book. 2016, 35, e72-e78. [CrossRef]

157. Lui, S.T.; Shuch, B. Genetic testing in kidney cancer patients: Who, when, and how? Eur. Urol. Focus 2019, 5, 973-976. [CrossRef]

158. Piccinin, C.; Panchal, S.; Watkins, N.; Kim, R.H. An update on genetic risk assessment and prevention: The role of genetic testing panels in breast cancer. Expert Rev. Anticancer Ther. 2019, 19, 787-801. [CrossRef]

159. Plichta, J.K.; Sebastian, M.L.; Smith, L.A.; Menendez, C.S.; Johnson, A.T.; Bays, S.M.; Euhus, D.M.; Clifford, E.J.; Jalali, M.; Kurtzman, S.H.; et al. Germline genetic testing: What the breast surgeon needs to know. Ann. Surg. Oncol. 2019, 26, 2184-2190. [CrossRef]

160. Valle, L.; Vilar, E.; Tavtigian, S.V.; Stoffel, E.M. Genetic predisposition to colorectal cancer: Syndromes, genes, classification of genetic variants and implications for precision medicine. J. Pathol. 2019, 247, 574-588. [CrossRef]

161. Suszynska, M.; Klonowska, K.; Jasinska, A.J.; Kozlowski, P. Large-scale meta-analysis of mutations identified in panels of breast/ovarian cancer-related genes-Providing evidence of cancer predisposition genes. Gynecol. Oncol. 2019, 153, 452-462. [CrossRef] [PubMed]

162. Muskens, I.S.; de Smith, A.J.; Zhang, C.; Hansen, H.M.; Morimoto, L.; Metayer, C.; Ma, X.; Walsh, K.M.; Wiemels, J.L. Germline cancer predisposition variants and pediatric glioma: A population-based study in California. Neuro. Oncol. 2020, 22, 864-874. [CrossRef] [PubMed]

163. Abdel-Rahman, M.H.; Sample, K.M.; Pilarski, R.; Walsh, T.; Grosel, T.; Kinnamon, D.; Boru, G.; Massengill, J.B.; Schoenfield, L.; Kelly, B.; et al. Whole exome sequencing identifies candidate genes associated with hereditary predisposition to uveal melanoma. Ophthalmology 2020, 127, 668-678. [CrossRef] [PubMed] 
164. Johansson, P.A.; Nathan, V.; Bourke, L.M.; Palmer, J.M.; Zhang, T.; Symmons, J.; Howlie, M.; Patch, A.M.; Read, J.; Holland, E.A.; et al. Evaluation of the contribution of germline variants in BRCA1 and BRCA2 to uveal and cutaneous melanoma. Melanoma Res. 2019, 29, 483-490. [CrossRef] [PubMed]

165. Shivakumar, M.; Miller, J.E.; Dasari, V.R.; Gogoi, R.; Kim, D. Exome-wide rare variant analysis from the discovEHR study identifies novel candidate predisposition genes for endometrial cancer. Front. Oncol. 2019, 9, 574. [CrossRef]

166. Bertelsen, B.; Tuxen, I.V.; Yde, C.W.; Gabrielaite, M.; Torp, M.H.; Kinalis, S.; Oestrup, O.; Rohrberg, K.; Spangaard, I.; Santoni-Rugiu, E.; et al. High. frequency of pathogenic germline variants within homologous recombination repair in patients with advanced cancer. NPJ Genom. Med. 2019, 4, 13. [CrossRef]

167. Akhavanfard, S.; Padmanabhan, R.; Yehia, L.; Cheng, F.; Eng, C. Comprehensive germline genomic profiles of children, adolescents and young adults with solid tumors. Nat. Commun. 2020, 11, 2206. [CrossRef]

168. Jin, Z.B.; Li, Z.; Liu, Z.; Jiang, Y.; Cai, X.B.; Wu, J. Identification of de novo germline mutations and causal genes for sporadic diseases using trio-based whole-exome/genome sequencing. Biol. Rev. Camb. Philos. Soc. 2018, 93, 1014-1031. [CrossRef]

169. Johnson, L.M.; Hamilton, K.V.; Valdez, J.M.; Knapp, E.; Baker, J.N.; Nichols, K.E. Ethical considerations surrounding germline next-generation sequencing of children with cancer. Expert Rev. Mol. Diagn. 2017, 17, 523-534. [CrossRef]

170. Stadler, Z.K.; Schrader, K.A.; Vijai, J.; Robson, M.E.; Offit, K. Cancer genomics and inherited risk. J. Clin. Oncol. 2014, 32, 687-698. [CrossRef]

171. Backman, S.; Bajic, D.; Crona, J.; Hellman, P.; Skogseid, B.; Stalberg, P. Whole genome sequencing of apparently mutation-negative MEN1 patients. Eur. J. Endocrinol. 2020, 182, 35-45. [CrossRef] [PubMed]

172. Nissim, S.; Leshchiner, I.; Mancias, J.D.; Greenblatt, M.B.; Maertens, O.; Cassa, C.A.; Rosenfeld, J.A.; Cox, A.G.; Hedgepeth, J.; Wucherpfennig, J.I.; et al. Mutations in RABL3 alter KRAS prenylation and are associated with hereditary pancreatic cancer. Nat. Genet. 2019, 51, 1308-1314. [CrossRef] [PubMed]

173. Okur, V.; Chung, W.K. The impact of hereditary cancer gene panels on clinical care and lessons learned. Cold Spring Harb. Mol. Case Stud. 2017, 3. [CrossRef] [PubMed]

174. Lumish, H.S.; Steinfeld, H.; Koval, C.; Russo, D.; Levinson, E.; Wynn, J.; Duong, J.; Chung, W.K. Impact of panel gene testing for hereditary breast and ovarian cancer on patients. J. Genet. Couns. 2017, 26, 1116-1129. [CrossRef] [PubMed]

175. Rosenthal, E.T.; Bernhisel, R.; Brown, K.; Kidd, J.; Manley, S. Clinical testing with a panel of 25 genes associated with increased cancer risk results in a significant increase in clinically significant findings across a broad range of cancer histories. Cancer Genet. 2017, 218-219, 58-68. [CrossRef]

176. Foley, S.B.; Rios, J.J.; Mgbemena, V.E.; Robinson, L.S.; Hampel, H.L.; Toland, A.E.; Durham, L.; Ross, T.S. Use of whole genome sequencing for diagnosis and discovery in the cancer genetics clinic. Ebiomedicine 2015, 2, 74-81. [CrossRef]

177. Fewings, E.; Larionov, A.; Redman, J.; Goldgraben, M.A.; Scarth, J.; Richardson, S.; Brewer, C.; Davidson, R.; Ellis, I.; Evans, D.G.; et al. Germline pathogenic variants in PALB2 and other cancer-predisposing genes in families with hereditary diffuse gastric cancer without CDH1 mutation: A whole-exome sequencing study. Lancet Gastroenterol. Hepatol. 2018, 3, 489-498. [CrossRef]

178. Richards, S.; Aziz, N.; Bale, S.; Bick, D.; Das, S.; Gastier-Foster, J.; Grody, W.W.; Hegde, M.; Lyon, E.; Spector, E.; et al. Standards and guidelines for the interpretation of sequence variants: A joint consensus recommendation of the American College of Medical Genetics and Genomics and the Association for Molecular Pathology. Genet. Med. 2015, 17, 405-424. [CrossRef]

179. Eccles, D.M.; Mitchell, G.; Monteiro, A.N.; Schmutzler, R.; Couch, F.J.; Spurdle, A.B.; Gomez-Garcia, E.B.; ENIGMA Clinical Working Group. BRCA1 and BRCA2 genetic testing-pitfalls and recommendations for managing variants of uncertain clinical significance. Ann. Oncol. 2015, 26, 2057-2065. [CrossRef]

180. Li, M.M.; Datto, M.; Duncavage, E.J.; Kulkarni, S.; Lindeman, N.I.; Roy, S.; Tsimberidou, A.M.; Vnencak-Jones, C.L.; Wolff, D.J.; Younes, A.; et al. Standards and guidelines for the interpretation and reporting of sequence variants in cancer: A joint consensus recommendation of the Association for Molecular Pathology, American Society of Clinical Oncology, and College of American Pathologists. J. Mol. Diagn. 2017, 19, 4-23. [CrossRef]

181. Hoffman-Andrews, L. The known unknown: The challenges of genetic variants of uncertain significance in clinical practice. J. Law Biosci. 2017, 4, 648-657. [CrossRef] [PubMed] 
182. Cheon, J.Y.; Mozersky, J.; Cook-Deegan, R. Variants of uncertain significance in BRCA: A harbinger of ethical and policy issues to come? Genome. Med. 2014, 6, 121. [CrossRef] [PubMed]

183. Welsh, J.L.; Hoskin, T.L.; Day, C.N.; Thomas, A.S.; Cogswell, J.A.; Couch, F.J.; Boughey, J.C. Clinical decision-making in patients with variant of uncertain significance in BRCA1 or BRCA2 Genes. Ann. Surg. Oncol. 2017, 24, 3067-3072. [CrossRef] [PubMed]

184. Voelker, R. Quick uptakes: Taking the uncertainty out of interpreting BRCA variants. J. Am. Med. Assoc. 2019, 321, 1340-1341. [CrossRef]

185. Domchek, S.; Weber, B.L. Genetic variants of uncertain significance: Flies in the ointment. J. Clin. Oncol. 2008, 26, 16-17. [PubMed]

186. Medendorp, N.M.; Hillen, M.A.; Murugesu, L.; Aalfs, C.M.; Stiggelbout, A.M.; Smets, E.M.A. Uncertainty related to multigene panel testing for cancer: A qualitative study on counsellors' and counselees' views. J. Community Genet. 2019, 10, 303-312. [CrossRef]

187. Medendorp, N.M.; Hillen, M.A.; van Maarschalkerweerd, P.E.A.; Aalfs, C.M.; Ausems, M.; Verhoef, S.; van der Kolk, L.E.; Berger, L.P.V.; Wevers, M.R.; Wagner, A.; et al. "We don't know for sure": Discussion of uncertainty concerning multigene panel testing during initial cancer genetic consultations. Fam. Cancer 2020, 19, 65-76. [CrossRef]

188. Hamilton, J.G.; Robson, M.E. Psychosocial effects of multigene panel testing in the context of cancer genomics. Hastings Cent. Rep. 2019, 49, S44-S52. [CrossRef]

189. Afghahi, A.; AWKuria. The changing landscape of genetic testing for inherited breast cancer predisposition. Curr. Treat Option Oncol. 2017, 18, 27. [CrossRef]

190. Richter, S.; Haroun, I.; Graham, T.C.; Eisen, A.; Kiss, A.; Warner, E. Variants of unknown significance in BRCA testing: Impact on risk perception, worry, prevention and counseling. Ann. Oncol. 2013, 24, viii69-viii74. [CrossRef]

191. Idos, G.E.; Kurian, A.W.; Ricker, C.; Sturgeon, D.; Culver, J.O.; Kingham, K.E.; Koff, R.; Chun, N.M.; Rowe-Teeter, C.; Lebensohn, A.P.; et al. Multicenter prospective cohort study of the diagnostic yield and patient experience of multiplex gene panel testing for hereditary cancer risk. JCO Precis. Oncol. 2019. [CrossRef]

192. Federici, G.; Soddu, S. Variants of uncertain significance in the era of high-throughput genome sequencing: A lesson from breast and ovary cancers. J. Exp. Clin. Cancer Res. 2020, 39, 46. [CrossRef] [PubMed]

193. Valencia, C.A.; Husami, A.; Holle, J.; Johnson, J.A.; Qian, Y.; Mathur, A.; Wei, C.; Indugula, S.R.; Zou, F.; Meng, H.; et al. Clinical impact and cost-effectiveness of whole exome sequencing as a diagnostic tool: A pediatric center's experience. Front. Pediatr. 2015, 3, 67. [CrossRef] [PubMed]

194. Gieldon, L.; Mackenroth, L.; Kahlert, A.K.; Lemke, J.R.; Porrmann, J.; Schallner, J.; von der Hagen, M.; Markus, S.; Weidensee, S.; Novotna, B.; et al. Diagnostic value of partial exome sequencing in developmental disorders. PLoS ONE 2018, 13, e0201041. [CrossRef] [PubMed]

195. Maxwell, K.N.; Hart, S.N.; Vijai, J.; Schrader, K.A.; Slavin, T.P.; Thomas, T.; Wubbenhorst, B.; Ravichandran, V.; Moore, R.M.; Hu, C.; et al. Evaluation of ACMG-guideline-based variant classification of cancer susceptibility and non-cancer-associated genes in families affected by breast cancer. Am. J. Hum. Genet. 2016, 98, 801-817. [CrossRef]

196. Eggington, J.M.; Bowles, K.R.; Moyes, K.; Manley, S.; Esterling, L.; Sizemore, S.; Rosenthal, E.; Theisen, A.; Saam, J.; Arnell, C.; et al. A comprehensive laboratory-based program for classification of variants of uncertain significance in hereditary cancer genes. Clin. Genet. 2014, 86, 229-237. [CrossRef]

197. Sud, A.; Kinnersley, B.; Houlston, R.S. Genome-wide association studies of cancer: Current insights and future perspectives. Nat. Rev. Cancer 2017, 17, 692-704. [CrossRef]

198. Turnbull, C.; Sud, A.; Houlston, R.S. Cancer genetics, precision prevention and a call to action. Nat. Genet. 2018, 50, 1212-1218. [CrossRef]

199. Kurian, A.W.; Hare, E.E.; Mills, M.A.; Kingham, K.E.; McPherson, L.; Whittemore, A.S.; McGuire, V.; Ladabaum, U.; Kobayashi, Y.; Lincoln, S.E.; et al. Clinical evaluation of a multiple-gene sequencing panel for hereditary cancer risk assessment. J. Clin. Oncol. 2014, 32, 2001-2009. [CrossRef]

200. Grissom, A.A.; Friend, P.J. Multigene panel testing for hereditary cancer risk. J. Adv. Pract. Oncol. 2016, 7, 394-407.

201. Kurian, A.W.; Ford, J.M. Multigene panel testing in oncology practice: How should we respond? JAMA Oncol. 2015, 1, 277-278. [CrossRef] [PubMed] 
202. Secretary's Advisory Committee on Genetics, Health and Society. Genetics Education and Training; The Honorable Kathleen Sebelius Secretary of Health and Human Services: Washington, DC, USA, 2011.

203. Campion, M.; Goldgar, C.; Hopkin, R.J.; Prows, C.A.; Dasgupta, S. Genomic education for the next generation of health-care providers. Genet. Med. 2019, 21, 2422-2430. [CrossRef] [PubMed]

204. Guttmacher, A.E.; Porteous, M.E.; McInerney, J.D. Educating health-care professionals about genetics and genomics. Nat. Rev. Genet. 2007, 8, 151-157. [CrossRef] [PubMed]

205. Douma, K.F.; Smets, E.M.; Allain, D.C. Non-genetic health professionals' attitude towards, knowledge of and skills in discussing and ordering genetic testing for hereditary cancer. Fam. Cancer 2016, 15, 341-350. [CrossRef] [PubMed]

206. Maiese, D.R.; Keehn, A.; Lyon, M.; Flannery, D.; Watson, M.; Working Groups of the National Coordinating Center for Seven Regional Genetics Service Collaboratives. Current conditions in medical genetics practice. Genet. Med. 2019, 21, 1874-1877. [CrossRef] [PubMed]

207. Salari, K. The dawning era of personalized medicine exposes a gap in medical education. PLoS Med. 2009, 6, e1000138. [CrossRef]

208. Stoll, K.; Kubendran, S.; Cohen, S.A. The past, present and future of service delivery in genetic counseling: Keeping up in the era of precision medicine. Am. J. Med. Genet. C Semin. Med. Genet. 2018, 178, $24-37$. [CrossRef]

209. Daly, M.B.; Stearman, B.; Masny, A.; Sein, E.; Mazzoni, S. How to establish a high-risk cancer genetics clinic: Limitations and successes. Curr. Oncol. Rep. 2005, 7, 469-474. [CrossRef]

210. Cohen, S.A.; Bradbury, A.; Henderson, V.; Hoskins, K.; Bednar, E.; Arun, B.K. Genetic counseling and testing in a community setting: Quality, access, and efficiency. Am. Soc. Clin. Oncol. Educ. Book. 2019, 39, e34-e44. [CrossRef]

211. Stopfer, J.E. Genetic counseling and clinical cancer genetics services. Semin. Surg. Oncol. 2000, 18, 347-357. [CrossRef]

212. Anderson, B.; McLosky, J.; Wasilevich, E.; Lyon-Callo, S.; Duquette, D.; Copeland, G. Barriers and facilitators for utilization of genetic counseling and risk assessment services in young female breast cancer survivors. J. Cancer Epidemiol. 2012, 2012, 298745. [CrossRef] [PubMed]

213. Cohen, S.A.; Marvin, M.L.; Riley, B.D.; Vig, H.S.; Rousseau, J.A.; Gustafson, S.L. Identification of genetic counseling service delivery models in practice: A report from the NSGC service delivery model task force. J. Genet. Couns. 2013, 22, 411-421. [CrossRef] [PubMed]

214. Ricker, C.; Lagos, V.; Feldman, N.; Hiyama, S.; Fuentes, S.; Kumar, V.; Farwell Hagman, K.; Palomares, M.; Blazer, K.; Lowstuter, K.; et al. If we build it ... will they come?-Establishing a cancer genetics services clinic for an underserved predominantly Latina cohort. J. Genet. Couns. 2007, 15, 505-514. [CrossRef]

215. Epstein, C.J.; Erickson, R.P.; Hall, B.D.; Golbus, M.S. The center-satellite system for the wide-scale distribution of genetic counseling services. Am. J. Hum. Genet. 1975, 27, 322-332. [PubMed]

216. Reid, K.J.; Sakati, N.; Prichard, L.L.; Schneiderman, L.J.; Jones, O.W.; Dixson, B.K. Genetic counseling: An evaluation of public health genetic clinics. West. J. Med. 1976, 124, 6-12. [PubMed]

217. Riccardi, V.M. Health care and disease prevention through genetic counseling: A regional approach. Am. J. Public Health 1976, 66, 268-272. [CrossRef]

218. Weissman, S.M.; Zellmer, K.; Gill, N.; Wham, D. Implementing a virtual health telemedicine program. in a community setting. J. Genet. Couns. 2018, 27, 323-325. [CrossRef]

219. Brown, J.; Athens, A.; Tait, D.L.; Crane, E.K.; Higgins, R.V.; Naumann, R.W.; Gusic, L.H.; Amacker-North, L. A comprehensive program: Enabling effective delivery of regional genetic counseling. Int. J. Gynecol. Cancer 2018, 28, 996-1002. [CrossRef]

220. Fournier, D.M.; Bazzell, A.F.; Dains, J.E. Comparing outcomes of genetic counseling options in breast and ovarian cancer: An integrative review. Oncol. Nurs. Forum 2018, 45, 96-105. [CrossRef]

221. Buchanan, A.H.; Rahm, A.K.; Williams, J.L. Alternate service delivery models in cancer genetic counseling: A mini-review. Front. Oncol. 2016, 6, 120. [CrossRef]

222. McDonald, E.; Lamb, A.; Grillo, B.; Lucas, L.; Miesfeldt, S. Acceptability of telemedicine and other cancer genetic counseling models of service delivery in geographically remote settings. J. Genet. Couns. 2014, 23, 221-228. [CrossRef] [PubMed] 
223. MacDonald, D.J.; KRBlazer; JNWeitze. Extending comprehensive cancer center expertise in clinical cancer genetics and genomics to diverse communities: The power of partnership. J. Natl. Compr. Canc. Netw. 2010, 8, 615-624. [CrossRef] [PubMed]

224. Solomon, I.B.; McGraw, S.; Shen, J.; Albayrak, A.; Alterovitz, G.; Davies, M.; Fitz, C.D.V.; Freedman, R.A.; Lopez, L.N.; Sholl, L.M. Engaging patients in precision oncology: development and usability of a web-based patient-facing genomic sequencing report. JCO Precis. Oncol. 2020, 4, 307-318. [CrossRef]

225. Blazer, K.R.; Macdonald, D.J.; Culver, J.O.; Huizenga, C.R.; Morgan, R.J.; Uman, G.C.; Weitzel, J.N. Personalized cancer genetics training for personalized medicine: Improving community-based healthcare through a genetically literate workforce. Genet. Med. 2011, 13, 832-840. [CrossRef] [PubMed]

226. Whitworth, P.; Beitsch, P.; Arnell, C.; Cox, H.C.; Brown, K.; Kidd, J.; Lancaster, J.M. Impact of payer constraints on access to genetic testing. J. Oncol. Pract. 2017, 13, e47-e56. [CrossRef] [PubMed]

227. Karlovich, C.A.; Williams, P.M. Clinical applications of next-generation sequencing in precision oncology. Cancer J. 2019, 25, 264-271. [CrossRef]

228. Wadapurkar, R.; Vyas, R. Computational analysis of next generation sequencing data and its applications in clinical oncology. Inform. Med. Unlocked 2018, 11, 75-82. [CrossRef]

229. Hyman, D.M.; Taylor, B.S.; Baselga, J. Implementing genome-driven oncology. Cell 2017, 168, $584-599$. [CrossRef]

230. Nangalia, J.; Campbell, P.J. Genome sequencing during a patient's journey through cancer. N. Engl. J. Med. 2019, 381, 2145-2156. [CrossRef]

231. Pleasance, E.D.; Cheetham, R.K.; Stephens, P.J.; McBride, D.J.; Humphray, S.J.; Greenman, C.D.; Varela, I.; Lin, M.L.; Ordonez, G.R.; Bignell, G.R.; et al. A comprehensive catalogue of somatic mutations from a human cancer genome. Nature 2010, 463, 191-196. [CrossRef]

232. Campbell, P.J.; Getz, G.; Korbel, J.O.; Stuart, J.M.; Jennings, J.L.; Stein, L.D.; Perry, M.D.; Nahal-Bose, H.K.; Ouellette, B.F.F.; Li, C.H.; et al. Pan-cancer analysis of whole genomes. Nature 2020, 578, 82-93.

233. Demircioglu, D.; Cukuroglu, E.; Kindermans, M.; Nandi, T.; Calabrese, C.; Fonseca, N.A.; Kahles, A.; Lehmann, K.V.; Stegle, O.; Brazma, A.; et al. A pan-cancer transcriptome analysis reveals pervasive regulation through alternative promoters. Cell 2019, 178, 1465-1477. [CrossRef] [PubMed]

234. Nagahashi, M.; Shimada, Y.; Ichikawa, H.; Kameyama, H.; Takabe, K.; Okuda, S.; Wakai, T. Next generation sequencing-based gene panel tests for the management of solid tumors. Cancer Sci. 2019, 110, 6-15. [CrossRef] [PubMed]

235. El Achi, H.; Khoury, J.D.; Loghavi, S. Liquid biopsy by next-generation sequencing: A multimodality test for management of cancer. Curr. Hematol. Malig. Rep. 2019, 14, 358-367. [CrossRef] [PubMed]

236. Kancherla, J.; Rao, S.; Bhuvaneshwar, K.; Riggins, R.B.; Beckman, R.A.; Madhavan, S.; Bravo, H.C.; Boca, S.M. Evidence-based network approach to recommending targeted cancer therapies. JCO Clin. Cancer Inform. 2020, 4, 71-88. [CrossRef]

237. Zhang, W.; Chien, J.; Yong, J.; Kuang, R. Network-based machine learning and graph theory algorithms for precision oncology. NPJ Precis. Oncol. 2017, 1, 25. [CrossRef]

238. Jiang, X.L.; Martinez-Ledesma, E.; Morcos, F. Revealing protein networks and gene-drug connectivity in cancer from direct information. Sci. Rep. 2017, 7, 3739. [CrossRef]

239. Zhang, Y.; Tao, C. Network analysis of cancer-focused association network reveals distinct network association patterns. Cancer Inform. 2014, 13, 45-51.

240. Cheng, F.; Liu, C.; Jiang, J.; Lu, W.; Li, W.; Liu, G.; Zhou, W.; Huang, J.; Tang, Y. Prediction of drug-target interactions and drug repositioning via network-based inference. PLoS Comput. Biol. 2012, 8, e1002503. [CrossRef]

241. Garber, K. In a major shift, cancer drugs go "tissue-agnostic". Science 2017, 356, 1111-1112. [CrossRef]

242. Luoh, S.W.; Flaherty, K.T. When tissue is no longer the issue: tissue-agnostic cancer therapy comes of age. Ann. Intern. Med. 2018, 169, 233-239. [CrossRef] [PubMed]

243. Mullard, A. FDA approves landmark tissue-agnostic cancer drug. Nat. Rev. Drug Discov. 2018, 1, 87. [CrossRef] [PubMed]

244. Torres-Ayuso, P.; Sahoo, S.; Ashton, G.; An, E.; Simms, N.; Galvin, M.; Leong, H.S.; Frese, K.K.; Simpson, K.; Cook, N.; et al. Signaling pathway screening platforms are an efficient approach to identify therapeutic targets in cancers that lack known driver mutations: A case report for a cancer of unknown primary origin. NPJ Genom. Med. 2018, 3, 15. [CrossRef] [PubMed] 
245. Siu, L.L.; Conley, B.A.; Boerner, S.; LoRusso, P.M. Next-generation sequencing to guide clinical trials. Clin. Cancer Res. 2015, 21, 4536-4544. [CrossRef] [PubMed]

246. Beaubier, N.; Bontrager, M.; Huether, R.; Igartua, C.; Lau, D.; Tell, R.; Bobe, A.M.; Bush, S.; Chang, A.L.; Hoskinson, D.C.; et al. Integrated genomic profiling expands clinical options for patients with cancer. Nat. Biotechnol. 2019, 37, 1351-1360. [CrossRef]

247. Lih, C.J.; Harrington, R.D.; Sims, D.J.; Harper, K.N.; Bouk, C.H.; Datta, V.; Yau, J.; Singh, R.R.; Routbort, M.J.; Luthra, R.; et al. Analytical validation of the next-generation sequencing assay for a nationwide signal-Finding clinical trial: Molecular analysis for therapy choice clinical trial. J. Mol. Diagn. 2017, 19, 313-327. [CrossRef]

248. Bitzer, M.; Ostermann, L.; Horger, M.; Biskup, S.; Schulze, M.; Ruhm, K.; Hilke, F.; Öner, Ö.; Nikolaou, K.; Schroeder, C.; et al. Next-generation sequencing of advanced gi tumors reveals individual treatment options. JCO Precis. Oncol. 2020, 4, 258-271. [CrossRef]

249. Sicklick, J.K.; Kato, S.; Okamura, R.; Schwaederle, M.; Hahn, M.E.; Williams, C.B.; De, P.; Krie, A.; Piccioni, D.E.; Miller, V.A.; et al. Molecular profiling of cancer patients enables personalized combination therapy: The I-PREDICT study. Nat. Med. 2019, 25, 744-750. [CrossRef]

250. Rodon, J.; Soria, J.C.; Berger, R.; Miller, W.H.; Rubin, E.; Kugel, A.; Tsimberidou, A.; Saintigny, P.; Ackerstein, A.; Brana, I.; et al. Genomic and transcriptomic profiling expands precision cancer medicine: The WINTHER trial. Nat. Med. 2019, 25, 751-758. [CrossRef]

251. Rothwell, D.G.; Ayub, M.; Cook, N.; Thistlethwaite, F.; Carter, L.; Dean, E.; Smith, N.; Villa, S.; Dransfield, J.; Clipson, A.; et al. Utility of ctDNA to support patient selection for early phase clinical trials: The TARGET study. Nat. Med. 2019, 25, 738-743. [CrossRef]

252. Reitsma, M.; Fox, J.; Vanden Borre, P.; Cavanaugh, M.; Chudnovsky, Y.; Erlich, R.L.; Gribbin, T.E.; Anhorn, R. Effect of a collaboration between a health plan, oncology practice, and comprehensive genomic profiling company from the payer perspective. J. Manag. Care Spec. Pharm. 2019, 25, 601-611. [CrossRef] [PubMed]

253. Luh, F.; Yen, Y. Benefits and harms of the centers for medicare \& medicaid services ruling on next-generation sequencing. JAMA Oncol. 2018, 4, 1171-1172. [PubMed]

254. Phillips, K.A.; Trosman, J.R.; Deverka, P.A.; Quinn, B.; Tunis, S.; Neumann, P.J.; Chambers, J.D.; Garrison, L.P., Jr.; Douglas, M.P.; Weldon, C.B. Insurance coverage for genomic tests. Science 2018, 360, 278-279.

255. Trosman, J.R.; Weldon, C.B.; Gradishar, W.J.; Benson, A.; Cristofanilli, M.; Kurian, A.W.; Ford, J.M.; Balch, A.; Watkins, J.; Phillips, K.A. From the past to the present: Insurer coverage frameworks for next-generation tumor sequencing. Value Health 2018, 21, 1062-1068. [CrossRef] [PubMed]

256. Freedman, A.N.; Klabunde, C.N.; Wiant, K.; Enewold, L.; Gray, S.W.; Filipski, K.K.; Keating, N.L.; Leonard, D.G.B.; Lively, T.; McNeel, T.S.; et al. Use of next-generation sequencing tests to guide cancer treatment: Results from a nationally representative survey of oncologists in the United States. JCO Precision Oncol. 2018, 13, 1-13. [CrossRef]

257. Miller, F.A.; Krueger, P.; Christensen, R.J.; Ahern, C.; Carter, R.F.; Kamel-Reid, S. Postal survey of physicians and laboratories: Practices and perceptions of molecular oncology testing. BMC Health Serv. Res. 2009, 9, 131. [CrossRef]

258. Gray, S.W.; Hicks-Courant, K.; Cronin, A.; Rollins, B.J.; Weeks, J.C. Physicians' attitudes about multiplex tumor genomic testing. J. Clin. Oncol. 2014, 32, 1317-1323. [CrossRef]

259. Gray, S.W.; Park, E.R.; Najita, J.; Martins, Y.; Traeger, L.; Bair, E.; Gagne, J.; Garber, J.; Janne, P.A.; Lindeman, N.; et al. Oncologists' and cancer patients' views on whole-exome sequencing and incidental findings: Results from the CanSeq study. Genet. Med. 2016, 18, 1011-1019. [CrossRef]

260. Malone, E.R.; Oliva, M.; Sabatini, P.J.B.; Stockley, T.L.; Siu, L.L. Molecular profiling for precision cancer therapies. Genome Med. 2020, 12, 8. [CrossRef]

261. Bieg-Bourne, C.C.; Millis, S.Z.; Piccioni, D.E.; Fanta, P.T.; Goldberg, M.E.; Chmielecki, J.; Parker, B.A.; Kurzrock, R. Next-generation sequencing in the clinical setting clarifies patient characteristics and potential actionability. Cancer Res. 2017, 77, 6313-6320. [CrossRef]

262. Clark, D.F.; Maxwell, K.N.; Powers, J.; Lieberman, D.B.; Ebrahimzadeh, J.; Long, J.M.; McKenna, D.; Shah, P.; Bradbury, A.; Morrissette, J.J.D.; et al. Identification and confirmation of potentially actionable germline mutations in tumor-only genomic sequencing. JCO Precis. Oncol. 2019, 3. [CrossRef] 
263. Madhavan, S.; Subramaniam, S.; Brown, T.D.; Chen, J.L. Art and challenges of precision medicine: Interpreting and integrating genomic data into clinical practice. Am. Soc. Clin. Oncol. Educ. Book. Educ. Book. 2018, 38, 546-553. [CrossRef] [PubMed]

264. Gutierrez, M.E.; Choi, K.; Lanman, R.B.; Licitra, E.J.; Skrzypczak, S.M.; Pe Benito, R.; Wu, T.; Arunajadai, S.; Kaur, S.; Harper, H.; et al. Genomic profiling of advanced non-small cell lung cancer in community settings: Gaps and opportunities. Clin. Lung. Cancer 2017, 18, 651-659. [CrossRef]

265. Trosman, J.R.; Weldon, C.B.; Kelley, R.K.; Phillips, K.A. Challenges of coverage policy development for next-generation tumor sequencing panels: Experts and payers weigh in. J. Natl. Compr. Canc. Netw. 2015, 13, 311-318. [CrossRef] [PubMed]

266. Hughes, K.S.; Ambinder, E.P.; Hess, G.P.; Yu, P.P.; Bernstam, E.V.; Routbort, M.J.; Clemenceau, J.R.; Hamm, J.T.; Febbo, P.G.; Domchek, S.M.; et al. Identifying health information technology needs of oncologists to facilitate the adoption of genomic medicine: Recommendations from the 2016 American Society of Clinical Oncology Omics and Precision Oncology Workshop. J. Clin. Oncol. 2017, 35, 3153-3159. [CrossRef]

267. Griffith, M.; Spies, N.C.; Krysiak, K.; McMichael, J.F.; Coffman, A.C.; Danos, A.M.; Ainscough, B.J.; Ramirez, C.A.; Rieke, D.T.; Kujan, L.; et al. CIViC is a community knowledgebase for expert crowdsourcing the clinical interpretation of variants in cancer. Nat. Genet. 2017, 49, 170-174. [CrossRef] [PubMed]

268. Chakravarty, D.; Phillips, S.; Kundra, R.; Zhang, H.; Wang, J.; Rudolph, J.E.; Yaeger, R.; Soumerai, T.; Nissan, M.H.; Chang, M.T.; et al. OncoKB: A precision oncology knowledge base. JCO Precis. Oncol. 2017. [CrossRef] [PubMed]

269. Kurnit, K.C.; Bailey, A.M.; Zeng, J.; Johnson, A.M.; Shufean, M.A.; Brusco, L.; Litzenburger, B.C.; Sanchez, N.S.; Khotskaya, Y.B.; Holla, V.; et al. "Personalized cancer therapy": A publicly available precision oncology resource. Cancer Res. 2017, 77, e123-e126. [CrossRef]

270. My Cancer Genome: Genetically Informed Cancer Medicine. Available online: https://www. mycancergenome.org/ (accessed on 25 April 2020).

271. Warner, J.L.; Prasad, I.; Bennett, M.; Arniella, M.; Beeghly-Fadiel, A.; Mandl, K.D.; Alterovitz, G. SMART cancer navigator: A framework for implementing ASCO workshop recommendations to enable precision cancer medicine. JCO Precis. Oncol. 2018. [CrossRef]

272. City of Hope. Molecular Oncology. Available online: https://www.cityofhope.org/clinical-moleculardiagnostic-laboratory/list-of-cmdl-tests/molecular-oncology (accessed on 3 June 2020).

273. Ellis, P.G. Development and implementation of oncology care pathways in an integrated care network: The via oncology pathways experience. J. Oncol. Pract. 2013, 9, 171-173. [CrossRef]

274. Luchini, C.; Lawlor, R.T.; Milella, M.; Scarpa, A. Molecular tumor boards in clinical practice. Trends Cancer 2020. [CrossRef]

275. Rolfo, C.; Manca, P.; Salgado, R.; Van Dam, P.; Dendooven, A.; Machado Coelho, A.; Ferri Gandia, J.; Rutten, A.; Lybaert, W.; Vermeij, J.; et al. Multidisciplinary molecular tumour board: A tool to improve clinical practice and selection accrual for clinical trials in patients with cancer. ESMO Open. 2018, 3, e000398. [CrossRef] [PubMed]

276. Remon, J.; Dienstmann, R. Precision oncology: Separating the wheat from the chaff. ESMO Open 2018, 3 , e000446. [CrossRef] [PubMed]

277. Romero, D. Optimizing access to matched therapies. Nat. Rev. Clin. Oncol. 2019, 16, 401. [CrossRef] [PubMed]

278. Andre, F.; Mardis, E.; Salm, M.; Soria, J.C.; Siu, L.L.; Swanton, C. Prioritizing targets for precision cancer medicine. Ann. Oncol. 2014, 25, 2295-2303. [CrossRef] [PubMed]

279. Dalton, W.S.; Sullivan, D.; Ecsedy, J.; Caligiuri, M.A. Patient enrichment for precision-based cancer clinical trials: Using prospective cohort surveillance as an approach to improve clinical trials. Clin. Pharmacol. Ther. 2018, 104, 23-26. [CrossRef] [PubMed]

280. Chakradhar, S. Matching up. Nat. Med. 2018, 24, 882-884. [CrossRef]

281. Roychowdhury, S.; Iyer, M.K.; Robinson, D.R.; Lonigro, R.J.; Wu, Y.M.; Cao, X.; Kalyana-Sundaram, S.; Sam, L.; Balbin, O.A.; Quist, M.J.; et al. Personalized oncology through integrative high-throughput sequencing: A pilot study. Sci. Transl. Med. 2011, 3, 111ra121. [CrossRef]

282. Kurnit, K.C.; Dumbrava, E.E.I.; Litzenburger, B.; Khotskaya, Y.B.; Johnson, A.M.; Yap, T.A.; Rodon, J.; Zeng, J.; Shufean, M.A.; Bailey, A.M.; et al. Precision oncology decision support: Current approaches and strategies for the future. Clin. Cancer Res. 2018, 24, 2719-2731. [CrossRef] 
283. Dalton, W.B.; Forde, P.M.; Kang, H.; Connolly, R.M.; Stearns, V.; Gocke, C.D.; Eshleman, J.R.; Axilbund, J.; Petry, D.; Geoghegan, C.; et al. Personalized medicine in the oncology clinic: Implementation and outcomes of the Johns Hopkins Molecular Tumor Board. JCO Precis. Oncol. 2017. [CrossRef]

284. Meric-Bernstam, F.; Johnson, A.; Holla, V.; Bailey, A.M.; Brusco, L.; Chen, K.; Routbort, M.; Patel, K.P.; Zeng, J.; Kopetz, S.; et al. A decision support framework for genomically informed investigational cancer therapy. J. Natl. Cancer Inst. 2015, 107. [CrossRef]

285. Hyman, D.M.; Solit, D.B.; Arcila, M.E.; Cheng, D.T.; Sabbatini, P.; Baselga, J.; Berger, M.F.; Ladanyi, M. Precision medicine at Memorial Sloan Kettering Cancer Center: Clinical next-generation sequencing enabling next-generation targeted therapy trials. Drug Discov. Today 2015, 20, 1422-1428. [CrossRef] [PubMed]

286. Huang, L.D.; Fernandes, H.; Zia, H.; Tavassoli, P.; Rennert, H.; Pisapia, D.; Imielinski, M.; Sboner, A.; Rubin, M.A.; Kluk, M.; et al. The cancer precision medicine knowledge base for structured clinical-grade mutations and interpretations. J. Am. Med. Inform. Assoc. 2017, 24, 513-519. [CrossRef] [PubMed]

287. Beltran, H.; Eng, K.; Mosquera, J.M.; Sigaras, A.; Romanel, A.; Rennert, H.; Kossai, M.; Pauli, C.; Faltas, B.; Fontugne, J.; et al. Whole-exome sequencing of metastatic cancer and biomarkers of treatment response. JAMA Oncol. 2015, 1, 466-474. [CrossRef] [PubMed]

288. Schwaederle, M.; Parker, B.A.; Schwab, R.B.; Daniels, G.A.; Piccioni, D.E.; Kesari, S.; Helsten, T.L.; Bazhenova, L.A.; Romero, J.; Fanta, P.T.; et al. Precision oncology: The UC San Diego Moores Cancer Center PREDICT Experience. Mol. Cancer Ther. 2016, 15, 743-752. [CrossRef] [PubMed]

289. Said, R.; Tsimberidou, A.M. Basket trials and the MD Anderson Precision Medicine Clinical trials platform. Cancer J. 2019, 25, 282-286. [CrossRef] [PubMed]

290. Trivedi, H.; Acharya, D.; Chamarthy, U.; Meunier, J.; Ali-Ahmad, H.; Hamdan, M.; Herman, J.; Srkalovic, G. Implementation and outcomes of a molecular tumor board at Herbert-Herman Cancer Center, Sparrow Hospital. Acta Med. Acad. 2019, 48, 105-115.

291. Grandori, C.; Kemp, C.J. Personalized cancer models for target. discovery and precision medicine. Trends Cancer 2018, 4, 634-642. [CrossRef]

292. Pauli, C.; Hopkins, B.D.; Prandi, D.; Shaw, R.; Fedrizzi, T.; Sboner, A.; Sailer, V.; Augello, M.; Puca, L.; Rosati, R.; et al. Personalized in vitro and in vivo cancer models to guide precision medicine. Cancer Discov. 2017, 7, 462-477. [CrossRef]

293. Chen, H.Z.; Bonneville, R.; Roychowdhury, S. Implementing precision cancer medicine in the genomic era. Semin. Cancer Biol. 2019, 55, 16-27. [CrossRef]

294. Wong, C.H.; Siah, K.W.; Lo, A.W. Estimation of clinical trial success rates and related parameters. Biostatistics 2019, 20, 273-286. [CrossRef] [PubMed]

295. Sacks, L.V.; Shamsuddin, H.H.; Yasinskaya, Y.I.; Bouri, K.; Lanthier, M.L.; Sherman, R.E. Scientific and regulatory reasons for delay and denial of FDA approval of initial applications for new drugs, 2000-2012. J. Am. Med. Assoc. 2014, 311, 378-384. [CrossRef] [PubMed]

296. Hay, M.; Thomas, D.W.; Craighead, J.L.; Economides, C.; Rosenthal, J. Clinical development success rates for investigational drugs. Nat. Biotechnol. 2014, 32, 40-51. [CrossRef] [PubMed]

297. Fogel, D.B. Factors associated with clinical trials that fail and opportunities for improving the likelihood of success: A review. Contemp. Clin. Trials Commun. 2018, 11, 156-164. [CrossRef] [PubMed]

298. Khozin, S.; Liu, K.; Jarow, J.P.; Pazdur, R. Regulatory watch: Why do oncology drugs fail to gain US regulatory approval? Nat. Rev. Drug. Discov. 2015, 14, 450-451. [CrossRef]

299. Heneghan, C.; Goldacre, B.; Mahtani, K.R. Why clinical trial outcomes fail to translate into benefits for patients. Trials 2017, 18, 122. [CrossRef]

300. Seruga, B.; Ocana, A.; Amir, E.; Tannock, I.F. Failures in phase III: Causes and consequences. Clin. Cancer Res. 2015, 21, 4552-4560. [CrossRef]

301. Schmidt, C. The struggle to do no harm. Nature 2017, 552, S74-S75. [CrossRef]

302. Mullard, A. How much do phase III trials cost? Nat. Rev. Drug Discov. 2018, 1, 7777-7777. [CrossRef]

303. Vincent Rajkumar, S. The high cost of prescription drugs: Causes and solutions. Blood Cancer J. 2020, 10, 71. [CrossRef]

304. Sanders, A.B.; Fulginiti, J.V.; Witzke, D.B.; Bangs, K.A. Characteristics influencing career decisions of academic and nonacademic emergency physicians. Ann. Emerg. Med. 1994, 23, 81-87. [CrossRef]

305. Tsang, J.L.Y.; Ross, K. It's time to increase community hospital-based health research. Acad. Med. 2017, 92, 727. [CrossRef] 
306. Dimond, E.P.; St Germain, D.; Nacpil, L.M.; Zaren, H.A.; Swanson, S.M.; Minnick, C.; Carrigan, A.; Denicoff, A.M.; Igo, K.E.; Acoba, J.D.; et al. Creating a "culture of research" in a community hospital: Strategies and tools from the National Cancer Institute Community Cancer Centers Program. Clin. Trials 2015, 12, 246-256. [CrossRef]

307. Boaz, A.; Hanney, S.; Jones, T.; Soper, B. Does the engagement of clinicians and organisations in research improve healthcare performance: A three-stage review. BMJ Open 2015, 5, e009415. [CrossRef]

308. Knepper, T.C.; Bell, G.C.; Hicks, J.K.; Padron, E.; Teer, J.K.; Vo, T.T.; Gillis, N.K.; Mason, N.T.; McLeod, H.L.; Walko, C.M. Key lessons learned from moffitt's molecular tumor board: The clinical genomics action committee experience. Oncologist 2017, 22, 144-151. [CrossRef] [PubMed]

309. Overman, M.J.; Morris, V.; Kee, B.; Fogelman, D.; Xiao, L.; Eng, C.; Dasari, A.; Shroff, R.; Mazard, T.; Shaw, K.; et al. Utility of a molecular prescreening program in advanced colorectal cancer for enrollment on biomarker-selected clinical trials. Ann. Oncol. 2016, 27, 1068-1074. [CrossRef] [PubMed]

310. Dienstmann, R.; Garralda, E.; Aguilar, S.; Sala, G.; Viaplana, C.; Ruiz-Pace, F.; González-Zorelle, J.; LoGiacco, D.G.; Ogbah, Z.; Masdeu, L.R.; et al. Evolving landscape of molecular prescreening strategies for oncology early clinical trials. JCO Precis. Oncol. 2020, 4, 505-513. [CrossRef]

311. Pishvaian, M.J.; Blais, E.M.; Bender, R.J.; Rao, S.; Boca, S.M.; Chung, V.; Hendifar, A.E.; Mikhail, S.; Sohal, D.P.S.; Pohlmann, P.R.; et al. A virtual molecular tumor board to improve efficiency and scalability of delivering precision oncology to physicians and their patients. JAMIA Open 2019, 2, 505-515. [CrossRef]

312. Schwaederle, M.; Zhao, M.; Lee, J.J.; Lazar, V.; Leyland-Jones, B.; Schilsky, R.L.; Mendelsohn, J.; Kurzrock, R. Association of biomarker-based treatment strategies with response rates and progression-free survival in refractory malignant neoplasms: A meta-analysis. JAMA Oncol. 2016, 2, 1452-1459. [CrossRef]

313. Schwaederle, M.; Zhao, M.; Lee, J.J.; Eggermont, A.M.; Schilsky, R.L.; Mendelsohn, J.; Lazar, V.; Kurzrock, R. Impact of precision medicine in diverse cancers: A meta-analysis of phase II clinical trials. J. Clin. Oncol. 2015, 33, 3817-3825. [CrossRef]

314. Stockley, T.L.; Oza, A.M.; Berman, H.K.; Leighl, N.B.; Knox, J.J.; Shepherd, F.A.; Chen, E.X.; Krzyzanowska, M.K.; Dhani, N.; Joshua, A.M.; et al. Molecular profiling of advanced solid tumors and patient outcomes with genotype-matched clinical trials: The Princess Margaret IMPACT/COMPACT trial. Genome Med. 2016, 8, 109. [CrossRef] [PubMed]

315. Haslem, D.S.; Van Norman, S.B.; Fulde, G.; Knighton, A.J.; Belnap, T.; Butler, A.M.; Rhagunath, S.; Newman, D.; Gilbert, H.; Tudor, B.P.; et al. A retrospective analysis of precision medicine outcomes in patients with advanced cancer reveals improved progression-free survival without increased health care costs. J. Oncol. Pract. 2017, 13, e108-e119. [CrossRef] [PubMed]

316. Radovich, M.; Kiel, P.J.; Nance, S.M.; Niland, E.E.; Parsley, M.E.; Ferguson, M.E.; Jiang, G.; Ammakkanavar, N.R.; Einhorn, L.H.; Cheng, L.; et al. Clinical benefit of a precision medicine based approach for guiding treatment of refractory cancers. Oncotarget 2016, 7, 56491-56500. [CrossRef]

317. Aust, S.; Schwameis, R.; Gagic, T.; Mullauer, L.; Langthaler, E.; Prager, G.; Grech, C.; Reinthaller, A.; Krainer, M.; Pils, D.; et al. Precision medicine tumor boards: Clinical applicability of personalized treatment concepts in ovarian cancer. Cancers 2020, 12, 548. [CrossRef] [PubMed]

318. Tafe, L.J.; Gorlov, I.P.; de Abreu, F.B.; Lefferts, J.A.; Liu, X.; Pettus, J.R.; Marotti, J.D.; Bloch, K.J.; Memoli, V.A.; Suriawinata, A.A.; et al. Implementation of a molecular tumor board: The impact on treatment decisions for 35 patients evaluated at Dartmouth-Hitchcock Medical Center. Oncologist 2015, 20, 1011-1018. [CrossRef]

319. Lamping, M.; Benary, M.; Leyvraz, S.; Messerschmidt, C.; Blanc, E.; Kessler, T.; Schutte, M.; Lenze, D.; Johrens, K.; Burock, S.; et al. Support of a molecular tumour board by an evidence-based decision management system for precision oncology. Eur. J. Cancer 2020, 127, 41-51. [CrossRef]

320. Boddu, S.; Walko, C.M.; Bienasz, S.; Bui, M.M.; Henderson-Jackson, E.; Naghavi, A.O.; Mullinax, J.E.; Joyce, D.M.; Binitie, O.; Letson, G.D.; et al. Clinical utility of genomic profiling in the treatment of advanced sarcomas: A single-center experience. JCO Precis. Oncol. 2018, 1-8. [CrossRef]

321. Lane, B.R.; Bissonnette, J.; Waldherr, T.; Ritz-Holland, D.; Chesla, D.; Cottingham, S.L.; Alberta, S.; Liu, C.; Thompson, A.B.; Graveel, C.; et al. Development of a center for personalized cancer care at a regional cancer center: Feasibility trial of an institutional tumor sequencing advisory board. J. Mol. Diagn. 2015, 17, 695-704. [CrossRef] 
322. Overton, L.C.; Corless, C.L.; Agrawal, M.; Assikis, V.J.; Beegle, N.L.; Blau, S.; Chernoff, M.; Divers, S.G.; Henry, D.H.; Nikolinakos, P.; et al. Impact of next-generation sequencing (NGS) on treatment decisions in the community oncology setting. J. Clin. Oncol. 2014, 32, 11028-11028. [CrossRef]

323. ASCO eLearning. Multidisciplinary Molecular Tumor Boards (MMTBs). Available online: https://elearning. asco.org/product-details/multidisciplinary-molecular-tumor-boards-mmtbs (accessed on 1 May 2020).

324. Healio Learn Genomics. Available online: https://www.healio.com/hematology-oncology/learn-genomics (accessed on 1 May 2020).

325. Pishvaian, M.J.; Bender, R.J.; Halverson, D.; Rahib, L.; Hendifar, A.E.; Mikhail, S.; Chung, V.; Picozzi, V.J.; Sohal, D.; Blais, E.M.; et al. Molecular profiling of patients with pancreatic cancer: Initial results from the know your tumor initiative. Clin. Cancer Res. 2018, 24, 5018-5027. [CrossRef]

326. Burkard, M.E.; Deming, D.A.; Parsons, B.M.; Kenny, P.A.; Schuh, M.R.; Leal, T.; Uboha, N.; Lang, J.M.; Thompson, M.A.; Warren, R.; et al. Implementation and clinical utility of an integrated academic-community regional molecular tumor board. JCO Precis. Oncol. 2017, 1-10. [CrossRef]

327. Heifetz, L.J.; Christensen, S.D.; Devere-White, R.W.; Meyers, F.J. A model for rural oncology. J. Oncol. Pract. 2011, 7, 168-171. [CrossRef] [PubMed]

328. Shea, C.M.; Teal, R.; Haynes-Maslow, L.; McIntyre, M.; Weiner, B.J.; Wheeler, S.B.; Jacobs, S.R.; Mayer, D.K.; Young, M.; Shea, T.C. Assessing the feasibility of a virtual tumor board program: A case study. J. Healthc. Manag. 2014, 59, 177-193. [CrossRef] [PubMed]

329. Farhangfar, C. Utilization of consultative molecular tumor board in community setting. J. Clin. Oncol. 2017, 35, 6508. [CrossRef]

330. Marshall, C.L.; Petersen, N.J.; Naik, A.D.; Vander Velde, N.; Artinyan, A.; Albo, D.; Berger, D.H.; Anaya, D.A. Implementation of a regional virtual tumor board: A prospective study evaluating feasibility and provider acceptance. Telemed. J. E Health 2014, 20, 705-711. [CrossRef]

331. Nasser, S.; Kurdolgu, A.A.; Izatt, T.; Aldrich, J.; Russell, M.L.; Christoforides, A.; Tembe, W.; Keifer, J.A.; Corneveaux, J.J.; Byron, S.A.; et al. An Integrated framework for reporting clinically relevant biomarkers from paired tumor/normal genomic and transcriptomic sequencing data in support of clinical trials in personalized medicine. Pac. Symp. Biocomput. 2015, 2015, 56-67.

332. Von Hoff, D.; Han, H. Precision Medicine in Cancer Therapy; Springer International Publishing: New York, NY, USA, 2019.

333. Weiss, G.J.; Byron, S.A.; Aldrich, J.; Sangal, A.; Barilla, H.; Kiefer, J.A.; Carpten, J.D.; Craig, D.W.; Whitsett, T.G. A prospective pilot study of genome-wide exome and transcriptome profiling in patients with small cell lung cancer progressing after first-line therapy. PLoS ONE 2017, 12, e0179170. [CrossRef]

334. Byron, S.A.; Tran, N.L.; Halperin, R.F.; Phillips, J.J.; Kuhn, J.G.; de Groot, J.F.; Colman, H.; Ligon, K.L.; Wen, P.Y.; Cloughesy, T.F.; et al. Prospective feasibility trial for genomics-informed treatment in recurrent and progressive glioblastoma. Clin. Cancer Res. 2018, 24, 295-305. [CrossRef]

335. Mueller, S.; Jain, P.; Liang, W.S.; Kilburn, L.; Kline, C.; Gupta, N.; Panditharatna, E.; Magge, S.N.; Zhang, B.; Zhu, Y.; et al. A pilot precision medicine trial for children with diffuse intrinsic pontine glioma-PNOC003: A report from the Pacific Pediatric Neuro-Oncology Consortium. Int. J. Cancer 2019, 145, 1889-1901. [CrossRef]

(C) 2020 by the authors. Licensee MDPI, Basel, Switzerland. This article is an open access article distributed under the terms and conditions of the Creative Commons Attribution (CC BY) license (http://creativecommons.org/licenses/by/4.0/). 